\title{
The importance of vitamin E for farmed fish-A review
}

\author{
Abdel-Fattah M. El-Sayed ${ }^{1}$ (๑) | Marisol Izquierdo ${ }^{2}$
}

${ }^{1}$ Oceanography Department, Faculty of Science, Alexandria University, Alexandria, Egypt

${ }^{2}$ IU-ECOAQUA, Universidad de Las Palmas de Gran Canaria, Telde, Spain

\section{Correspondence}

Abdel-Fattah M. El-Sayed, Oceanography Department, Faculty of Science,

Alexandria University, Alexandria, Egypt. Email: Abdelfatah.youssif@alexu.edu.eg

\begin{abstract}
Vitamin $E(V E)$ is composed of a group of fat-soluble molecules, from which the most active homologous is $\alpha$-tocopherol. VE is a structural component of cell membranes with a potent chain-breaking antioxidant action, which plays a main role in several biological processes. In cultured fish, VE can prevent peroxidation of cellular and subcellular membrane phospholipids and also red blood cells, leading to maintaining the structural and functional integrity of animal cells. VE performs several other biological and metabolic functions, including improvement of the immune response, enhancing growth performance and feed efficiency, preventing muscle degeneration, reducing the risk of atherosclerosis, improving reproductive efficiency and larval performance, meat quality and shelf life of seafood. Besides, VE interacts with other micronutrients, especially vitamin $C$ and selenium. Fish feed and fish flesh generally contain high concentrations of lipids, especially polyunsaturated fatty acids, which renders these lipids more susceptible to lipid peroxidation. Supplemental VE may, therefore, become necessary to prevent this peroxidation. However, the VE requirement of farmed aquatic animals varies significantly, depending on dietary contents of VC, selenium and lipid (unsaturated fatty acids). This review summarizes the current knowledge on the physiological functions of VE in farmed fish and shrimp, and the effects of supplemental VE on fish performance, reproduction, health and product quality. The future considerations of VE requirements of farmed fish in light of the predicted climate change have also been discussed, especially with regard to feed input supplies (fish meal and fish oil vs. plant proteins and oils) and weather temperature.
\end{abstract}

\section{KEYWORDS}

antioxidant, fish, lipids, selenium, vitamin $\mathrm{E}$, vitamin $\mathrm{E} /$ vitamin $\mathrm{C}$ interaction

\section{1 | INTRODUCTION}

Vitamin E (VE) is a term that includes a group of fat-soluble molecules, from which the most active homologous is $\alpha$-tocopherol. Thus, VE comprises at least ten homologous derivatives of a 6-chromanol ring with a phytyl side chain, including tocopherols, tocotrienols and tocomonoenols. Among them, $\alpha$-tocopherol (5, 7, 8-trimethyl tocol) $(\alpha-\mathrm{TOH})$ is the most widely distributed form of VE, with the highest biological activity and biopotency, in relation to its selective uptake and transport. ${ }^{1,2}$ VE is a structural component of cell membranes with a potent chain-breaking antioxidant action, which plays a main role in several biological processes. In cultured fish and shrimps, VE improves growth and feed utilization; promotes health status and contributes to regulate the immune system and selenium (Se) metabolism; enhances reproductive performance and larval development and improves fillet quality and shelf life. ${ }^{3}$ Therefore, VE has always been added in aquafeeds, for almost all studied fish and crustacean species. $^{4}$

In recent years, a large bulk of research has been devoted to determining the effects of VE on fish and shrimp performance, antioxidation, immunity, quality, and other biological activities and metabolic functions. These issues have been comprehensively 
reviewed by Hamre, ${ }^{3}$ who deeply analysed and interpreted the published works on the role of VE in aquaculture. However, during the last decade, over 200 documents have been published on the role of VE in aquaculture and its effects on the quality of produced fish. Bringing all this diverse and scattered information to the target readers in a single review becomes necessary and timely. Nonetheless, a comprehensive review on this role is missing from current literature. A better understanding of the functions and applications of VE in aquaculture and its interactions with other nutrients is also lacking.

Therefore, this review analyses and discusses the published studies on the importance of VE for cultured finfish, with emphasis on the information published during recent years. The review was organized into five major sections: (1) role of VE in antioxidant protection; (2) interaction of VE with other dietary elements (namely vitamin C, lipids and selenium); (3) dietary VE requirements for growth, health and flesh quality of freshwater fish and marine fish; (4) dietary VE requirements for reproduction; and (5) future considerations. Other specific aspects of VE metabolism, such as absorption or transport, have been previously reviewed and are beyond the scope of this study. ${ }^{3-5}$

\section{2 | ROLE OF VITAMIN E IN ANTIOXIDANT PROTECTION}

Vitamin E is particularly important for fish and shrimps, since they are high in polyunsaturated fatty acids (PUFA), which are very susceptible to oxidation. Oxidation of PUFA results in the formation of a number of primary and secondary toxic products that can cause a wide range of problems in fish and shrimps, including oxidative stress, decrease in growth rates, reduction in immune response, loss of nutritive value, unpleasant flavour, or reduction of quality and shelf life. ${ }^{3,6-8}$ The peroxidation of fatty acid reduces membrane fluidity, increases the permeability of the membrane and inactivates membrane-bound enzymes. ${ }^{9}$ The antioxidant effects of VE have been widely investigated in several marine and freshwater fish. For instance, lipid peroxidation in liver and muscle was significantly reduced in juvenile Coho salmon (Oncorhynchus kisutch) fed high VE ( $\geq$ 50 IU VE kg ${ }^{-1}$ diet) compared to those fed a VE-free diet. ${ }^{10}$

Microcystins (MCs), which are a group of cyclic, water-soluble cyanotoxins produced by cyanobacteria and released into the water column can accumulate along the ecological food chain, resulting in animal poisoning. ${ }^{11} \mathrm{MCs}$ modulate antioxidant enzymes, leading to the formation of reactive oxygen species (ROS), which may cause oxidative damages to animal tissues. ${ }^{12,13}$ The protective effect of VE on MCs-induced oxidative damage in aquatic organisms has been demonstrated in Nile tilapia (Oreochromis niloticus). ${ }^{14}$ In this species, lipid peroxidation (LPO) increased when fish was exposed to MCs, whereas VE supplementation protected the fish from MCs-induced oxidative damage in a dose-response manner. Thus, VE supplementation enhances the activities of antioxidant enzymes, such as catalase (CAT), superoxide dismutase (SOD), glutathione peroxidase (GPX) and glutathione reductase (GR).
The accumulation of heavy metals, such as copper and cadmium, in the aquatic environment also promotes ROS production and inhibits antioxidant enzymes activities, leading to oxidative stress and impairment of antioxidant defence in fish. ${ }^{15}$ VE supplementation may counteract this oxidative damage and improve the performance of farmed fish. For instance, supplemental VE enhanced antioxidant defences in Nile tilapia fingerlings exposed to copperoxychloride. ${ }^{16}$ Dietary VE supplementation has also similar protective effects and enhancement of immune response in Nile tilapia, ${ }^{17}$ grass carp (Ctenopharyngodon idellus), ${ }^{18}$ yellow catfish (Pelteobagrus fulvidraco $^{19}$ and largemouth bass (Micropterus salmoides). ${ }^{20}$

In contrast with the above results, the protective role of VE supplementation against oxidative stress was not observed in other studies. This fact may be related to a series of factors such as fish species and size, water temperature, dietary lipid source or the interaction with other nutrients, which may affect VE efficiency as an antioxidant and also VE requirements. ${ }^{4,21-24}$ For example, feeding halibut (Hippoglossus hippoglossus) with oxidized oil does not increase the activity of antioxidant defence enzymes (GPX, GST and GR) and VE supplementation only reduced SOD. ${ }^{22}$ Similarly, dietary VE supplementation did not affect liver antioxidant enzymes activities, liver glutathione content, total mercapthans or phagocytic chemiluminescent response in Atlantic salmon smolt reared in freshwater, under normoxic and moderate oxidative stress. ${ }^{25,26}$ In salmonids, this moderate protective effect of VE against lipid peroxidation may be related to the presence of another antioxidant: astaxanthin. Astaxanthin can prevent VE from oxidation and in turn exhibit a vitamin-E-sparing effect. ${ }^{27,28}$ In addition, the high lipid contents in salmon diets may provide sufficient amount of VE, which may meet the VE requirement of these fish. ${ }^{25}$ This suggests that in diets for salmonids, it would be unnecessary to supplement VE to promote antioxidant defences, overall health and growth, if sufficient amounts of astaxanthin and VE are provided by the raw materials used in feed formulation.

The antioxidant efficacy of VE supplementation may also be dependent on the dietary lipid content or fish size and developmental stage. Thus, fish that require low dietary lipid levels (such as tilapia) need also low levels of VE compared with fish that require high dietary lipids. ${ }^{17,29}$ Moreover, the increase in dietary PUFA also raises the VE requirements for antioxidant protection, particularly in fast growing species and young fish. ${ }^{30-32}$ For instance, when gilthead seabream (Sparus aurata) larvae were fed increased dietary PUFA levels, elevation of VE supplementation improved growth, survival and PUFA contents in fish polar lipids. ${ }^{30}$ Early life stages also require more VE than older stages as has been shown in gilthead seabream, ${ }^{29,33}$ meagre (Argyrosomus regius) ${ }^{34-36}$ and European seabass (Dicentrarchus labrax). ${ }^{31}$

The relationship between VE requirement and water temperature is also evident. At low temperatures, fish must regulate membrane bilayer fluidity, which is essential for cellular function under cold stress. ${ }^{37,38}$ Under such conditions, membrane homeostasis is secured by the production of high levels of low molecular weight, unsaturated fatty acids in cellular membrane lipids. ${ }^{37,39}$ However, 
excessive production of unsaturated lipid makes cellular membranes more vulnerable to oxidative damage, which can impair cellular functions. Therefore, supplemental antioxidants such as VE can play a significant role in combating the fish cellular damage. This suggests that the VE requirement for fish increases with decreasing water temperature, as suggested by Cowey, Degener, Tacon, Youngson and Bell ${ }^{40}$ who reported that VE requirement of rainbow trout may increase with decreasing water temperature. VE supplementation also improved blood parameters, $\mathrm{ACH} 50$ and survival of golden shiner (Notemigonus crysoleucas) exposed to heat stress, compared with VE-deficient fish. ${ }^{41}$ Besides, dietary lipid levels and sources modulate the response of Nile tilapia to cold stress, ${ }^{42,43}$ supporting the adaptive role of VE against cold stress in aquatic organisms. ${ }^{38}$

The dietary levels of other antioxidants, or pro-oxidants, such as $\mathrm{VC}$ or selenium (Se) may also affect the VE requirements. ${ }^{3,29,36,44}$ In addition, the degree of lipid oxidation may affect the capability of fish to ingest these lipids and modulate their VE antioxidant response. For example, secondary lipid oxidation products (such as thiobarbituric acid-reactive substances; TBARs) have been reported to affect sensory characteristics of the oil, while primary lipid oxidation products (hydroperoxides) are odourless and tasteless. ${ }^{45}$ Therefore, some fish can ingest oxidized lipids, whereas other fish cannot.

\section{3 | INTERACTION OF VITAMIN E WITH OTHER DIETARY ELEMENTS}

\subsection{Interaction of vitamin E with vitamin C}

Vitamin C (VC) (ascorbic acid) is a water-soluble vitamin, which has an antioxidant potential, can reduce the oxidative stress in animals and inactivate oxidative free radicals produced by cellular activities or other stressors. ${ }^{46-48}$ Most of these radicals are reactive oxygen species (ROS), including hydrogen peroxide, hydroxyl radical and superoxide anion, which can damage cellular membrane components, such as lipids, carbohydrates, proteins and DNA. ${ }^{49}$ Thus, VC is considered a reducing agent (ie electron donor), playing a significant role as an antioxidant, which can scavenge the free radicals and ROS, and in turn, prevent cellular radical damage, protect cell membrane and cytosol substances and restore VE when both vitamins are available. The ability of VC to restore or spare VE from membrane $\alpha$ tocopherol radicals is necessary for its antioxidant function. ${ }^{50}$ This means that both VC and VE work synergistically as major antioxidants, growth promoters and immune response stimulators. They also perform many other physiological functions in farmed aquatic animals. ${ }^{1,47,51}$ However, VC cannot be synthesized in vivo, because fish lack L-gulonolactone oxidase enzyme, which is required for VC biosynthesis. ${ }^{52}$ Therefore, exogenous VC is essential for fish performance and physiological functions.

The VE-VC interaction has been investigated in several fish species, including gilthead sea bream, ${ }^{53-55}$ channel catfish (Ictalurus punctatus), ${ }^{56,57}$ red sea bream (Pagrus major), ${ }^{58}$ Atlantic salmon, ${ }^{59,60}$ rainbow trout, ${ }^{61}$ Nile tilapia, ${ }^{62}$ yellow perch (Perca flavescens), ${ }^{63}$ sturgeon (Acipenser fulvescens), ${ }^{64}$ meagre (Argyrosomus regius), ${ }^{35}$ Japanese flounder (Paralichthys olivaceus) ${ }^{65}$ and discus fish (Symphysodon haraldi). ${ }^{44}$ The interactive effects of these two vitamins on these fish species can lead to the following benefits.

\subsection{1 | Prevention of lipid peroxidation}

Malondialdehyde (MDA) is a highly reactive compound, formed as one of the products of lipid peroxidation, leading to cellular damage and dysfunction; therefore, it is considered a strong biomarker for oxidative stress. ${ }^{66}$ The activity of antioxidant enzymes, such as SOD, CAT or GPX, is also an indicator of lipid peroxidation and cellular damage. ${ }^{47}$ Increased secretion of these enzymes prevents lipid peroxidation and cellular damage.

The coexistence of VE and VC at appropriate ratios can exert synergistic antioxidant effects, leading to modulation of the abovementioned oxidative stress indicators, avoidance of cellular radical damage and prevention of lipid peroxidation. ${ }^{67}$ For example, high supplemental VC and VE in discus fish (Symphysodon haraldi) diets led to increasing total antioxidant capacity and decreasing total SOD activity. ${ }^{44}$ Also, high dietary VC concentration significantly reduced the levels of secondary lipid oxidation products (TBARs) in hybrid tilapia (Oreochromis niloticus $\times$ O. aureus) fed a VE-deficient diet. ${ }^{68}$ This finding suggests that VC can suppress lipid peroxidation and protect the cells against oxidative stress. Similar results were also reported on Atlantic salmon, ${ }^{60}$ channel catfish ${ }^{56,69,70}$ or European seabass, ${ }^{71}$ where dietary VC protected these fish from VE deficiency and increased their tissue concentrations of $\alpha$-tocopherol. The interactive effect of dietary VC and VE on lipid metabolism in red sea bream (Pagrus major) and black sea bream (Acanthopagrus schlegeli) has also been confirmed by Ji, Om, Yoshimatsu, Hayashi, Umino and Nakagawa. ${ }^{72}$

Both VC and VE are also involved in the hypothalamicsympathetic-chromaffin cell axis and interfere in stress responses, where they protect the leucocyte functions. ${ }^{54} \mathrm{VC}$ is also able to spare VE from membrane $\alpha$-tocopherol radicals, inducing an antioxidant function. ${ }^{50}$ Thus, VC interaction affects lipid metabolism by accelerating VE retention and/or preventing VE oxidation; suggesting the strong lipid antioxidant effect of VC, which acts synergistically with VE to improve fish health and vitality.

The VC-VE interaction mechanism has been related to the varying sensitivity to VE deficiency in farmed fish species. ${ }^{70,73}$ When channel catfish were fed VC-deficient diets, they exhibited reduced growth performance, regardless of VE supplementation. Also, symptoms of VE deficiency were not detected in fish fed a VE-deficient diet with supplemental VC. ${ }^{56,70}$ Similarly, the protective role of VC in the absence or deficiency of VE has been demonstrated in rainbow trout and Atlantic salmon. ${ }^{74,75}$

On the other hand, vitamins $\mathrm{C}$ and $\mathrm{E}$ can act as pro-oxidants in vivo when given in excess, causing oxidative stress. Excessive amounts of both vitamins may lead to a significant reduction and 
imbalance in the VC/VE ratio, and in turn, impair the amount of VC required for $V E$ restoration, as demonstrated in Atlantic salmon. ${ }^{59}$ This would lead to the accumulation of pro-oxidant tocopheroxyl radicals, which would promote irreversible oxidation of $\mathrm{VC}^{3}$ and reduce the $\mathrm{VC}$ content in fish body. ${ }^{29}$ The pro-oxidant effect of VC and VE has been demonstrated in sturgeon ${ }^{64}$; where excessive doses of VC or VE led to increased phospholipid peroxidation of dehydroascorbic acid reductase activity; causing adverse effects on physiological functions, including the pro-oxidative effects. Similarly, when gilthead seabream larvae were fed high levels of VC and VE (up to $3000 \mathrm{mg} \mathrm{kg}^{-1}$ ), the expression of antioxidant enzymes genes was up-regulated, bone anomalies were increased and survival was reduced, indicating a strong pro-oxidant effect. ${ }^{29}$ Moreover, dietary supplementation with taurine, another nutrient with antioxidant properties, mitigated these symptoms. ${ }^{29}$ These studies suggest that appropriate levels of VC and VE, and the ratio between them, are necessary for exerting their antioxidant effects and optimizing their metabolism. ${ }^{73,75}$ Meanwhile, the antioxidant synergism between VE and VC is expected to be more evident when high contents of PUFA are included in fish diets, as demonstrated in seabass larvae. ${ }^{71}$

\subsection{2 | Role of VE/VC ratio in improving fish growth and health status}

The ratio between vitamins $C$ and $E$ in fish feeds is essential for optimum growth, immune response and disease resistance. As mentioned above, both vitamins have synergistic effect on growth performance and health status of farmed aquatic animals. Earlier researches suggested a sparing effect of VC on VE when high levels of VC are supplemented to VE-deficient feeds. VE sparing has been reported in Atlantic salmon, ${ }^{60}$ hybrid tilapia ${ }^{68}$ and channel catfish. ${ }^{56}$ About 100 mg dietary VC kg ${ }^{-1}$ sufficiently improved growth and feed efficiency of Nile tilapia, whereas the amount of VE contained in the basal diet was sufficient to support fish performance. ${ }^{76}$ However, 50 mg VE kg ${ }^{-1}$ was necessary for optimum survival when dietary VC was deficient. Increasing dietary VC increased liver VE concentration, while supplemental VE did not affect liver VC. On the other hand, excessive dietary VC or VE did not improve the immune response. Supplemental VC at $100 \mathrm{mg} \mathrm{kg}^{-1}$ feed improved growth, feed efficiency, survival and haematological parameters, and prevented vertebral deformity in channel catfish fed diets with different VC. ${ }^{56}$ Increasing dietary VC increased liver $\alpha$-tocopherol, supporting the assumption of sparing effect of VC on VE. The growth of darkbarbel catfish (Pelteobagrus vachelli) also increased with increasing both dietary linolenic acid and VC levels, whereas a VC-deficient diet inhibited the activities of antioxidant enzymes, immunity and disease resistance. ${ }^{77}$ Meanwhile, higher VE levels improved immune responses against Aeromonas hydrophila challenge. ${ }^{78}$ This finding suggests that high dietary linolenic acid, VC and VE can enhance the immune response and resistance in darkbarbel catfish challenged with $A$. hydrophila.

\subsection{Interaction of VE with dietary fatty acids and oxidized oils}

As mentioned above (Role of VE in antioxidant protection), fish diets and tissues containing large amounts of highly unsaturated fatty acids (HUFA) are susceptible to lipid oxidation, releasing a number of toxic products, and causing several problems to animals. ${ }^{3,6-8,79,80}$ The presence of VE in fish body, as an antioxidant, prevents lipid oxidation, while decreased VE concentration decreases the VE/PUFA ratio. ${ }^{81}$ In addition, VE plays a significant role in the desaturation process of $n-3$ and n-6 PUFA, through the regulation of the microsomal electron chain, which is a part of the desaturase complex. ${ }^{82}$ This means that increasing dietary HUFA contents increases the requirement for VE in farmed fish. ${ }^{1,57,83,84}$ In support, vitamin $E$ requirement of common carp (Cyprinus carpio), ${ }^{85}$ blue tilapia (Oreochromis aureus), ${ }^{83}$ grouper (Epinephelus malabaricus) ${ }^{84}$ increased with increasing dietary lipid (PUFA) levels. In addition, Lim, Yildirim-Aksoy, Shelby, Li and Klesius ${ }^{57}$ found that VE concentration in channel catfish liver was related to dietary levels of VE, but was negatively correlated with dietary lipid (fish oil) levels. High supplementation of VE (200 mg kg ${ }^{-1}$ diet) significantly reduced liver VE at increasing dietary fish oil. These results support the role of VE as an antioxidant, preventing lipid oxidation.

Fish oils rich in PUFAs, especially n-3 HUFA such as eicosapentaenoic acid (EPA) and docosahexaenoic acid (DHA), are highly susceptible to peroxidation during processing and storage. ${ }^{9,22}$ This process generally leads to several negative impacts, including cell biomembrane damage, ${ }^{86,87}$ deterioration in animal health, growth and feed efficiency ${ }^{3,88}$ and product quality. ${ }^{7}$ The use of oxidized oil in fish feeds has also been reported to cause skeletal abnormalities, ${ }^{89}$ reduce blood glucose, ${ }^{90}$ increase haemoglobin level and glycolytic activity, ${ }^{91}$ and reduce VE concentration in fish tissues. ${ }^{92,93}$ These symptoms can be partially or totally alleviated when $\alpha$-tocopherol is supplemented at appropriate levels.

On the other hand, progression of lipid peroxidation of frozen seafood products leads to a decrease in $\alpha$-tocopherol concentrations in these products. ${ }^{94}$ This, in turn, leads to deterioration in the quality of seafood. Therefore, supplementation of VE to oxidized lipid in aquaculture feed has been shown to reduce lipid peroxidation and improve fish performance, health status and product quality, as demonstrated in sea bream (Acanthopagrus schlegeli), ${ }^{88}$ hybrid tilapia (Oreochromis niloticus $\times$ O. aureus) ${ }^{95}$ and turbot (Scophthalmus maximus) and gilthead sea bream (S. aurata). ${ }^{22,96}$

\subsection{Interaction of VE with dietary selenium}

Selenium (Se) is an indispensable trace element for living animals, due to the role it plays as an antioxidant. It is incorporated in glutathione peroxidases (GPX), which is an important defence wall against peroxidation, by oxidizing and destroying the free radicals (peroxides), and saving glutathione (GSH) in a reduced form. ${ }^{3}$ Both Se and VE are biological antioxidants, used to prevent the damage of 
cell membranes, caused by PUFA peroxidation. ${ }^{97}$ The presence of Se can reduce the $V E$ requirement for maintenance and can also help in retention of VE in animal tissues and in blood plasma lipoproteins. Similarly, VE has the ability to reduce Se requirement by preventing loss of Se from the body, or by maintaining its active form. This interaction leads to the reduction of the amount of GPX needed for peroxides destruction.

The interaction between VE and Se has been well investigated in many fish species, including rainbow trout (Oncorhynchus mykiss), ${ }^{98-101}$ grouper (Epinephelus malabaricus), ${ }^{102}$ yellowtail kingfish (Seriola lalandi), ${ }^{103,104}$ Nile tilapia (Oreochromis niloticus), ${ }^{105}$ largemouth bass (Micropterus salmoide) ${ }^{45}$ and hybrid striped bass (Morone chrysops $\times$ M. saxatilis). ${ }^{106}$ These studies demonstrated that VE and Se act synergistically and can spare the metabolic requirements of one another. Also, deficiency of dietary Se may result in reduced concentrations of tissue VE, whereas the deficiency of both micronutrients leads to anaemia, muscular dystrophy and proteins in plasma. ${ }^{70,107-109}$ This means that sufficient supplementation of either VE or Se can meet the deficiency of the other.

The positive interactive sparing effects between dietary Se and VE were demonstrated in grouper (E. malabaricus) ${ }^{102}$ and yellowtail kingfish (S. Ialandi). ${ }^{103}$ Increasing supplemental Se improved growth rates of fish fed diets containing low levels of (or deficient in) VE, whereas simultaneous application of both Se and VE improved growth and health indices. Also, dietary supplementation of Nano Se and/ or VE improved the growth, intestinal health, blood parameters, oxidative status, and immune-related gene expression of Nile tilapia (O. niloticus) ${ }^{105}$ and rainbow trout. ${ }^{98}$ The combination of both micronutrients also provides synergistic effects in modulating the high density stress-related haematological responses. This can prevent the effects of oxidative stress and improve antioxidant status and innate immune responses, as reported in rainbow trout. ${ }^{101} \mathrm{~A}$ combination of Nano Se, VC and VE also increased growth performance, antioxidant capacity and immunity in rainbow trout juveniles exposed to ammonia stress. ${ }^{110}$

Dietary supplementation of both VE and Se has also been found to protect fish from the oxidative damage against dietary oil oxidation. This effect has been attributed to the reduction of glutathione and liver and muscle malondialdehyde (MDA) contents, and suppression of hepatic catalase activities. ${ }^{45,105}$ For example, largemouth bass (M. salmoide) fed oxidized oil suffer from increased CAT activity, poor growth and impaired feed utilization, whereas Se supplementation increased liver and muscle lipid contents and VE lead to reduced hepatic catalase activities. ${ }^{45}$

On the contrary, studies on hybrid bass (Morone chrysops $\times M$. saxatilis) revealed that Se supplementation neither affects growth performance nor has any interaction with dietary VE. ${ }^{106,111}$ These studies suggested that the basal diets may have contained sufficient amount of Se to meet the fish requirement, as supported by the lack of Se deficiency signs in fish fed the basal diets without additional Se supplementation. The lack of synergistic effects of dietary VC, VE and Se on growth performance of Nile tilapia and their disease resistance to Edwardsiella tarda has also been documented. ${ }^{21}$ However, sufficient dietary supplementation of VE or VC (separately) significantly improved tilapia performance. It seems from these discussions that the metabolic response of fish to dietary VE and Se is species specific, depending on fish species and size, form and concentration of supplemental VE and Se, and the contents of these micronutrients in basal diets.

\section{DIETARY VITAMIN E REQUIREMENTS FOR GROWTH, HEALTH AND FLESH QUALITY}

It is known that animals neither biosynthesize tocopherols nor store them in large amounts in their bodies. ${ }^{112}$ Therefore, continuous supply of dietary VE is essential for animals' maintenance, growth and physiological functions. In this regard, several research papers have been published on the beneficial effects of dietary VE for growth, survival, feed efficiency, reproduction, antioxidant activity, and immune response of different farmed fish. Studied fish groups comprised several freshwater fish species, such as tilapia, ${ }^{62,95}$ channel catfish, ${ }^{56,57,113}$ African catfish, ${ }^{92,114}$ carps $^{18,115,116}$ and rainbow trout. $^{98-100,117,118}$ Marine species included sea breams, ${ }^{58,96,119,120}$ sea bass, ${ }^{20,45,71,121}$ salmons, ${ }^{26,122-124}$ cobia, $^{125}$ meagre ${ }^{34,35}$ and flounder. ${ }^{126-128}$

This section overviews and analyses these publications. For facilitating the topic and assisting the readers extract the necessary information on VE requirements, the major findings of these studies are summarized in a comprehensive table (Table 1). Most of the recorded results were obtained by broken line regression. It should be emphasized, however, that there is a number of interactions of VE with other nutrients, such as VC, selenium and dietary lipid levels and composition, which affect fish performance and health status (as reviewed in the above sections). Therefore, it is necessary to consider these interactions when determining the VE requirement of farmed fish. In addition, the VE requirement may differ from one response variable to another. In other words, the amount of VE required for growth, antioxidant capacity, immunity response, meat quality or reproductive efficiency can vary significantly among species, and even among different sizes in the same species.

\section{1 | Vitamin E requirements for freshwater fish}

As mentioned above, the $V E$ requirement of farmed fish varies significantly, depending on farmed species and size, dietary lipid sources and levels, and culture conditions (see Table 1 for details). The function for which VE is supplied also has a significant effect on its dietary requirement. Relatively low VE requirements were reported for a number of freshwater fish species, presumably due to the relatively low lipid contents in their diets. For example, about 40-66 mg $V E \mathrm{~kg}^{-1}$ feed was sufficient for improving growth performance of sub-adult Nile tilapia, ${ }^{17,129}$ whereas higher amounts (100-200 mg VE $\mathrm{kg}^{-1}$ ) were required for fingerlings. ${ }^{62}$ More than 10 -fold increase 
TABLE 1 A summary of the effects of vitamin E on performance and health status of different farmed fish species

\begin{tabular}{|c|c|c|c|c|}
\hline Species (wt. g fish ${ }^{-1}$ ) & \multicolumn{2}{|c|}{ VE level (mg kg ${ }^{-1}$ feed) } & Remarks & Reference \\
\hline $\begin{array}{l}\text { Nile tilapia (O. niloticus) } \\
\quad(79.37)\end{array}$ & $0-1000$ & $>40$ & $\begin{array}{l}\text { Higher levels }\left(574-582 \mathrm{mg} \mathrm{kg}^{-1} \text { ) were required for }\right. \\
\text { optimum fillet texture }\end{array}$ & 17 \\
\hline $\begin{array}{l}\text { GIFT Nile tilapia (O. } \\
\text { niloticus) (80.3) }\end{array}$ & $0-240$ & $\begin{array}{l}43.2-45.8 \text { (6\% lipid) } \\
66-76 \text { (13\% lipid) }\end{array}$ & $\begin{array}{l}\text { Requirement increased with increasing dietary } \\
\text { lipids }\end{array}$ & 129 \\
\hline $\begin{array}{l}\text { GIFT Nile tilapia (O. } \\
\text { niloticus) }(0.66)\end{array}$ & $0-320$ & $\begin{array}{l}80 \text { (growth) } \\
160-320 \text { (VER) }\end{array}$ & $\begin{array}{l}\text { VE deficiency reduced growth, fat metabolism and } \\
\text { disrupted the inflammatory response. Optimum } \\
\text { VE improved growth and the inflammatory } \\
\text { response and AC in fish exposed to S. iniae }\end{array}$ & 130 \\
\hline $\begin{array}{l}\text { Nile tilapia (O. niloticus) } \\
\quad(7.16)\end{array}$ & $0-200$ & $100-200$ & $\begin{array}{l}\text { Increasing dietary lipid to } 14 \% \text { decreased liver VE. } \\
\text { Immune response decreased in fish fed } 10 \text { or } \\
14 \% \text { lipids, but increased at } 100 \text { or } 200 \mathrm{mg} \\
\text { VE kg }\end{array}$ & 62 \\
\hline Grass carp (C. idella) (11.2) & $0-400$ & 100.36 & $\begin{array}{l}\text { VE supplementation improved growth rates and } \\
\text { enhanced AC }\end{array}$ & 18 \\
\hline Grass carp (C. idella) (266.4) & $0-225$ & $116.2-130.9$ & $\begin{array}{l}\text { VE deficiency depressed GR and immune } \\
\text { response, and disturbed structural integrity of } \\
\text { the skin, spleen and Kidney }\end{array}$ & 116 \\
\hline Rohu (L. rohita) (0.58) & $0-200$ & 131.91 & $\begin{array}{l}\text { Fish fed diets containing }<100 \mathrm{mg} \mathrm{VE} \mathrm{kg}^{-1} \text { had } \\
\quad \text { lower GR }\end{array}$ & 132 \\
\hline $\begin{array}{l}\text { Yellow catfish (P. fulvidraco) } \\
\quad(2.01)\end{array}$ & $19.6-156.9$ & $\begin{array}{l}33 \text { (growth) } \\
46 \text { (lysozyme) }\end{array}$ & $\begin{array}{l}\text { Dietary VE improved GR, FE, antioxidant activity } \\
\text { and cumulative survival following challenge } \\
\text { with } A \text {. hydrophila }\end{array}$ & 19 \\
\hline $\begin{array}{l}\text { Channel catfish (I. } \\
\text { punctatus) (5.2) }\end{array}$ & $0-1000$ & $50-100$ & $\begin{array}{l}\text { Dietary VE improved GR, digestive enzymes } \\
\text { activity and intestinal structure and function }\end{array}$ & 133 \\
\hline $\begin{array}{l}\text { Japanese eel }{ }^{\mathrm{a}} \text { (A. japonica) } \\
\quad(15)\end{array}$ & $0-120$ & $>21.2-<21.6$ & $\begin{array}{l}\text { VE improved GR and FE. GR was better at } 15 \mathrm{mg} \\
\text { VE kg }{ }^{-1} \text { than at other VE levels }\end{array}$ & 137 \\
\hline $\begin{array}{l}\text { Japanese eel (A. japonica) } \\
\qquad(360)\end{array}$ & $0-428$ & $\begin{array}{l}212.9 \text { (VER) } \\
428 \text { (immunity) }\end{array}$ & $\begin{array}{l}\text { VE levels in liver, kidney, muscles and gonads were } \\
\text { positively correlated with dietary VE }\end{array}$ & 24 \\
\hline $\begin{array}{l}\text { Snout bream (M. } \\
\text { amblycephala) (0.59) }\end{array}$ & $0-500$ & 55.5 & $\begin{array}{l}\text { Supplementation of VE improved GR and increased } \\
\text { EPA, DHA and total liver n-3 HUFA }\end{array}$ & 131 \\
\hline $\begin{array}{l}\text { Largemouth bass (M. } \\
\text { salmoides) (7.54) }\end{array}$ & $14.24-225.32$ & $\begin{array}{l}73 \text { (growth) } \\
108 \text { (VER) }\end{array}$ & $\begin{array}{l}\text { VE deficiency reduced GR, feed utilization, } \\
\text { antioxidant and immunity states }\end{array}$ & 20 \\
\hline \multicolumn{5}{|l|}{ Marine fish } \\
\hline $\begin{array}{l}\text { Gilthead seabream (S. } \\
\text { aurata) (150) }\end{array}$ & $100-1800$ & 1200 & $\begin{array}{l}\text { At } 1200 \mathrm{mg} \mathrm{VE} \mathrm{kg}^{-1} \text {, non-specific immune system } \\
\text { was stimulated. Lower or higher dietary VE } \\
\text { caused an imbalance in VE ratio with other } \\
\text { antioxidants }\end{array}$ & 140 \\
\hline $\begin{array}{l}\text { Gilthead seabream (S. } \\
\text { aurata) (5.66 mm TL) }\end{array}$ & $128-3281$ & 1783 & $\begin{array}{l}\text { Highest survival and GR and lowest incidence } \\
\text { of bone anomalies were achieved at } 1783 \text {, } \\
1921 \text { and } 7000 \mathrm{mg} \mathrm{kg}^{-1} \text { VE, VC and taurine, } \\
\text { respectively. Increasing dietary VE and VC to } \\
3000 \mathrm{mg} \mathrm{kg}^{-1} \text { led to unbalanced body VC/VE } \\
\text { ratio and highest bone anomalies }\end{array}$ & 29 \\
\hline
\end{tabular}


TABLE 1 (Continued)

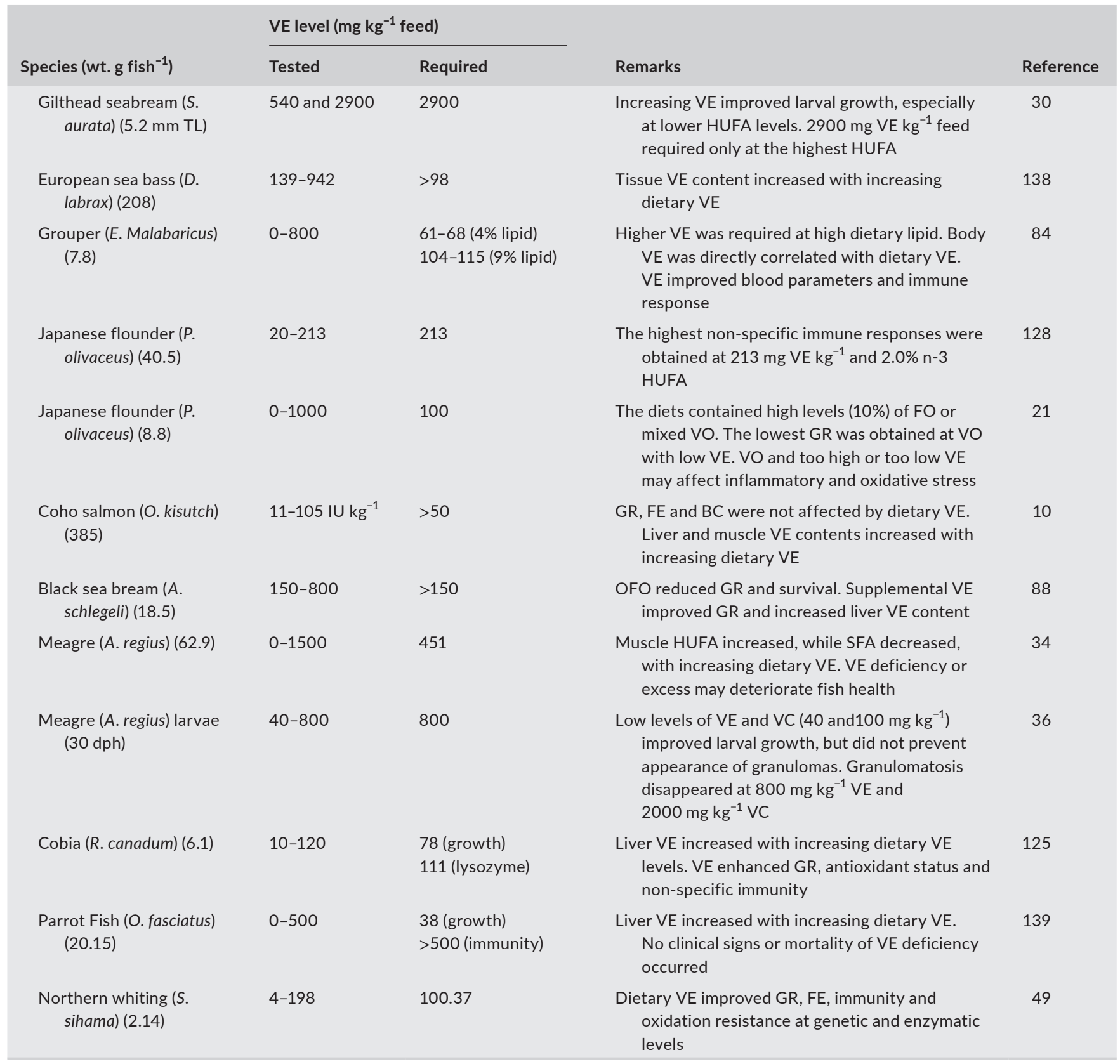

Abbreviations: ARA, arachidonic acid; AC, antioxidant capacity; ACA, alternative complement activity; ATPase, adenosine triphosphatase; BC, body composition; CA, catalase activity; DHA, docosahexaenoic acid; EPA, eicosapentaenoic acid; FT, fillet texture; FCR, feed conversion ratio; FE, feed efficiency; GIFT, genetically improved farmed tilapia; GR, growth rates; HUFA, highly unsaturated fatty acids; MDA, malondialdehyde; OFO, oxidized fish oil; RBA, respiratory burst activity; SFA, saturated fatty acids; SOD, superoxide dismutase; TAN, total ammonia nitrogen, TBARS, thiobarbituric acid-reactive substance; VC, vitamin C; VE, vitamin E; VER, vitamin E retention; VO, vegetable oils; WBC, white blood cells.

${ }^{a}$ Anguilla Japonica are catadromous fish; spawning in the sea, but live parts of their life in fresh water. They are farmed mainly in freshwater and brackish water environments.

in VE was needed for fillet texture and serum antioxidant capacity ${ }^{17}$ and for VE retention in fish flesh and activation of the immune system response and antioxidant capacity in fish challenged with Streptococcus iniae. ${ }^{130}$ A low dietary VE concentration $\left(55.5 \mathrm{mg} \mathrm{kg}^{-1}\right.$ ) was also required for optimum performance of a cyprinid fish, the Blunt snout bream (Megalobrama amblycephala) larvae $(0.59 \mathrm{~g}) .^{131}$ However, early life stages of grass carp (Ctenopharyngodon idellus) ${ }^{18,116}$ and rohu (Labeo rohita) ${ }^{132}$ require more VE than older stages.
A wide discrepancy in VE requirements of catfish has been reported by different authors. Small amounts of VE supported growth rates, feed efficiency and antioxidant activity of yellow catfish (Pelteobagrus fulvidraco) (33-45 mg kg$\left.{ }^{-1}\right)^{19}$ and channel catfish (Ictalurus punctatus) (50-100 mg VE kg-1). ${ }^{133}$ On the other hand, significantly higher amount of VE was required for optimum performance of darkbarbel catfish (Pelteobagrus vachelli). ${ }^{78}$ These discrepancies have been attributed to the differences in fish sizes and 
developmental stages, dietary lipid levels and sources, fatty acid composition and water temperature. For example, yellow catfish require much lower dietary lipid level (about 8-11\%) (Han et al ${ }^{130}$; than darkbarbel catfish (about 20\%), ${ }^{23}$ which may justify the higher VE requirement of the later species. In addition, dietary lipid sources (coconut oil, perilla oil, sunflower oil and fish oil + sunflower oil) and fatty acid profiles significantly influenced antioxidant activities and immune response in yellow catfish. ${ }^{134} \mathrm{Ma}$, Jin, Zhu, Li, Lu, Yuan, Xiong and Zhou ${ }^{135}$ found also that moderate levels of dietary arachidonic acid (ARA) improved growth performance and antioxidant response of yellow catfish. The optimum combination of lipid level and water temperature $\left(7.7 \%\right.$ and $\left.26.9^{\circ} \mathrm{C}\right)$ has also optimized growth performance, antioxidative activity and immune response of these fish. $^{136}$

The vitamin E requirement may also vary from one developmental stage to the other in the same species. Juvenile eel $(15 \mathrm{~g})$, for instance, require very little amount of VE $\left(21 \mathrm{mg} \mathrm{kg}^{-1}\right)$ for optimum growth, ${ }^{137}$ whereas sub-adult fish require much higher VE concentration in their diets for improving non-specific immune responses and high VE retention in the liver, kidney, muscles and gonads. ${ }^{24}$ It is obvious from these findings that several factors affect the VE requirements of farmed fish. These factors should be considered during the evaluation of $\mathrm{VE}$ requirements of farmed fish, in order to achieve reliable results, and to make sound comparisons.

\section{2 | Marine fish}

One may assume that the VE requirements for marine fish are higher than those reported for freshwater fish, due to the high lipid and n-3 HUFA levels in marine fish diets. However, this assumption may not be always true, since some marine fish require low levels of dietary VE for optimum performance. For example, grouper (Epinephelus Malabaricus), ${ }^{84}$ European sea bass, ${ }^{138}$ coho salmon ${ }^{10}$ and cobia (Rachycentron canadum) ${ }^{125}$ require less than $100 \mathrm{mg} \mathrm{VE} \mathrm{kg}^{-1}$ feed for optimum performance. Moreover, only $38 \mathrm{mg} \mathrm{VE} \mathrm{kg}^{-1}$ were sufficient to support the growth of parrotfish (Oplegnathus fasciatus), despite that $>500 \mathrm{mg} \mathrm{kg}^{-1}$ was required for optimum immune response. $^{139}$

On the contrary, some other marine fish species require much higher dietary VE levels for growth and health status. Sub-adult gilthead sea bream, for example, require $1200 \mathrm{mg} \mathrm{kg}^{-1}$ feed for optimum health status and non-specific immune response. ${ }^{140}$ In addition, much higher dietary VE supplementation is reported for larval sea bream. ${ }^{29,30}$ When the larvae were fed diets containing different levels of VC, VE and taurine, the highest survival, growth and osteocalcin gene expression and lowest incidence of bone anomalies were achieved at 1783, 1921 and $7000 \mathrm{mg} \mathrm{kg}^{-1} \mathrm{VE}, \mathrm{VC}$ and taurine, respectively. ${ }^{29}$ Moreover, when gilthead seabream larvae are fed extremely high dietary HUFA, even higher dietary VE levels seem to be needed for optimum performance. ${ }^{30}$ This particular study also shows the antioxidant effect of VE and suggests a higher protection value when HUFA are limiting. ${ }^{30}$ However, increasing dietary VE and
VC to $3000 \mathrm{mg} \mathrm{kg}^{-1}$ results in unbalanced body VC/VE ratio, upregulation of antioxidant enzymes genes, the highest incidence of bone anomalies and the lowest survival rates. ${ }^{29}$

The above-mentioned factors (fish sizes and growth stages, dietary lipid and fatty acid profiles, other micronutrients, water temperature, etc.) which affect the VE requirement of freshwater fish (see the above section) may also affect the response of marine fish to dietary VE. It has been documented that when marine fish larvae are fed on inert diets, they become highly susceptible to oxidative stress, due to the high dietary content of LC-PUFA and pro-oxidants such as minerals. ${ }^{3,30,71}$ Therefore, the inclusion of high dietary antioxidants such as VE becomes necessary to prevent oxidative damage and improve larval survival and performance, as reported in sea bass larvae. ${ }^{71}$ These studies also showed that the presence of other dietary nutrients such as VC, Se or taurine (and their ratios with VE) also modulates VE requirements for marine fish. ${ }^{29,71}$ Also in meagre, VE requirement $\left(800 \mathrm{mg} \mathrm{kg}^{-1}\right)$ is higher during early life stages than during later grow-out stages. ${ }^{36}$

\subsection{Effects of vitamin E on seafood quality}

It is well known that seafood is more susceptible to spoilage and oxidation during processing and storage than other food classes. This has been attributed to their high moisture contents, the presence of several volatile nitrogenous compounds with low molecular weights, the high contents of $n-3$ HUFA, especially in fatty fish, and the presence of psychrophilic bacteria, which can significantly reduce the quality of these products. ${ }^{7,141}$ As mentioned earlier, lipid peroxidation leads to the production of peroxyl radicals, free fatty acids and product rancidity. As lipid peroxidation continues, VE concentration in seafood decreases, ${ }^{94,142}$ which may further deteriorate the quality of seafood products. This means that seafood should contain sufficient amounts of $\alpha$-tocopherol to protect them against lipid oxidation. ${ }^{143-145}$

A number of studies indicated that supplemental dietary VE significantly improved product quality of different fish products. When Coho salmon was fed different types of antioxidants, a VEsupplemented diet resulted in the best sensory and physical properties of the long-term frozen salmon product. ${ }^{145}$ Fillet textural parameters, cohesiveness, resilience and chewiness of GIFT Nile tilapia were also significantly higher in fish fed VE-supplemented diets than in those offered a VE-deficient diet. ${ }^{17}$ The addition of VE also increased serum and muscle SOD and serum CAT activities, and decreased serum and muscle MDA levels, supporting the role of VE in antioxidant protection. Also, muscle HUFA in meagre (Argyrosomus regius) increased, and saturated fatty acids and TBARS values decreased, with increasing dietary VE. ${ }^{34}$ Similarly, a positive correlation was also found between dietary VE levels and the concentrations of $\alpha$-tocopherol in turbot (S. maximus) and Atlantic halibut (H. hippoglossus) ${ }^{146}$ and rainbow trout fillet. ${ }^{142}$ Prolonged feeding with high VE diets also increased the proportion of total USFAs, PUFAs and n-3 FAs, and decreased the proportion of saturated fatty acids (SFAs) 
and $n-6$ FAs. In addition, supplementation of tocopherols significantly reduced TBARS values in carp (Ciprinus carpio) fillets stored at $5^{\circ} \mathrm{C}$, compared with tocopherol-deficient samples. ${ }^{147}$

Vitamin E may also improve the fillet quality of fish fed oxidized fish oil (OFO), as has been demonstrated in red sea bream (Pagrus major). ${ }^{120}$ The OFO-fed fish had high fillet TBARS values, and low VC and VE concentrations during storage, compared with fish fed fresh oil. Also, increasing supplemental VE increased fillet VE levels and reduced fillet TBARS values, whereas VC supplementation did not affect fillet quality parameters. Thus, the positive effects of VE on fillet quality of fish fed OFO have been related to the reduction of lipid peroxidation, saturated fatty acids and TBARS values, in addition to increasing body VE contents. ${ }^{88,95,138}$ The dietary and tissue contents of other antioxidants such as VC and Se may also contribute the quality of fish fed OFO.

\section{5 | EFFECTS OF VITAMIN E ON REPRODUCTIVE PERFORMANCE}

The metabolic rates in rapidly growing tissues are high, which may result in the production of high concentrations of free radicals, as suggested by Rudneva II. ${ }^{148}$ This author found that the activity of antioxidant enzymes (lipoxygenase, SOD, CAT, peroxidase and glutathione reductase) in five Black Sea fish species increased during eggs development and in hatched larvae. This suggests that the presence of antioxidants is necessary for tissues protection against peroxidation, and therefore, VE may play a significant role in these metabolic processes. In this regard, high levels of VE were found in eggs and seminal fluid of European sea bass (Dicentrarchus labrax) before and after egg fertilization, and in embryos during development and at hatching, while low levels were observed in dead eggs and in embryos with low survival rates. ${ }^{149}$ These findings suggest that VE is vital for egg and larval development in these fish. In addition, dietary supplementation of VE and arachidonic acid (ARA) had synergistic effects on non-specific immune responses in Japanese eel (Anguilla japonica) broodstock. ${ }^{150} \mathrm{~A}$ linear correlation was also found between dietary VE and VE content in the ovarian tissue.

Consequently, the role of dietary VE in supporting gonadal development, reproductive processes, spawning performance and larval growth and survival has received considerable attention during the past two decades. The results of these researches are summarized in Table 2. These studies indicated that high dietary supplementation of VE can reduce egg deformity and abnormality and improve fish fecundity, egg development and larval quality, and also protect eggs from oxidation. ${ }^{151-155}$ VE can also improve sperm quality and protect sperm cells from oxidation. ${ }^{156,157}$

On the other hand, VE-deficient diets may produce immature gonads and decrease egg fertilization and hatchability and larval survival. ${ }^{153,156,158,159}$ When zebrafish (Danio rerio) ${ }^{159,160}$ and goldfish

TAB LE 2 Vitamin E requirement for optimum reproductive performance of farmed fish

\begin{tabular}{|c|c|c|c|c|}
\hline \multirow[b]{2}{*}{ Species } & \multicolumn{2}{|c|}{$\begin{array}{l}\text { Dietary vitamin E levels ( } \mathrm{mg} \mathrm{kg}^{-1} \\
\text { feed) }\end{array}$} & \multirow[b]{2}{*}{ Remarks } & \multirow[b]{2}{*}{ Reference } \\
\hline & Tested & Required & & \\
\hline Gilthead sea bream (S. aurata) & $22-2010$ & 2010 & $\begin{array}{l}\text { The diets contained different levels of HUFA (1.4- } \\
2.2 \%) . \text { Egg VE content increased only at very high } \\
\text { dietary VE levels }\left(2020 \mathrm{mg} \mathrm{kg}^{-1}\right) \text { at } 1.4 \% \text { HUFA }\end{array}$ & 153 \\
\hline Swordtail (X. helleri) & $0-1000$ & 500 & $\begin{array}{l}\text { Gonad weight and GSI increased with increasing } \\
\text { dietary VE up to } 500 \mathrm{mg} \mathrm{kg}^{-1} \text {, and declined } \\
\text { thereafter. Early embryo stages were dominant in } \\
\text { fish fed } 250 \text { and } 1000 \mathrm{mg} \mathrm{VE} \text {, whereas late stages } \\
\text { were dominant at } 500 \mathrm{mg} \mathrm{VE} \mathrm{kg}^{-1} \text { diet }\end{array}$ & 158 \\
\hline Nile tilapia (O. niloticus) & $200-500$ & 400 & $\begin{array}{l}\text { VE supplementation improved fecundity, spawning } \\
\text { frequency, hatchability, larval production and } \\
\text { survival. Fertilization rates, egg weight and } \\
\text { diameter were not affected by dietary VE }\end{array}$ & 154 \\
\hline Pindani (P. socolofi) & $121.3-270.0$ & 219.3 & $\begin{array}{l}\text { Reproductive performance, hatching rates and larval } \\
\text { survival increased with increasing dietary VE levels } \\
\text { up to } 219.3 \mathrm{~m} \mathrm{~kg}^{-1} \text {, then levelled off or declined }\end{array}$ & 155 \\
\hline Goldfish (C. auratus) & $0-600$ & 300 & $\begin{array}{l}\text { VE-lacking diet resulted in delayed spawning. Higher } \\
\text { fecundity and better hatchability were obtained at } \\
300 \mathrm{mg} \mathrm{VE} \mathrm{kg}^{-1} \text { feed }\end{array}$ & 161 \\
\hline
\end{tabular}


(Carassius auratus) broodstock ${ }^{161}$ were fed VE-deficient diets, they exhibited low fecundity and delayed spawning, and produced viable embryos with depleted VE concentrations, with higher malformation and mortality than embryos from broodstock fed VE-supplemented diets.

Vitamin E has been reported to mobilize (mainly via lipoproteins) from peripheral tissues during vitellogenesis in different fish species. ${ }^{162-164}$ When Japanese flounder Paralichthys olivaceus broodstock were fed a VE-supplemented diet (1000 mg kg-1), $\alpha$-tocopherol was associated with vitellogenesis and transported to, and preserved in, the gonads during the reproduction season. ${ }^{164}$ After spawning, serum $\alpha$-tocopherol was combined with the increasing lipoprotein. Besides, providing VE through primary pituitary cells in vitro stimulates the expression of gonadotropin hormones (follicle-stimulating hormone (FSH) and luteinizing hormone (LH)) in the pituitary of turbot (S. maximus). ${ }^{165}$

\section{6 | FUTURE CONSIDERATIONS}

Despite aquaculture's rapid expansion, its sustainability faces some menaces related to climate change, including sea-level rise, global warming, changes in rainfall patterns, changes in water salinity and uncertainty of feed inputs supplies. ${ }^{166}$ The expected impacts of climate change on aquaculture production include direct changes (physical, behavioural and physiological changes of farmed species in the production systems) and indirect changes (altering wind and water circulation, the primary and secondary productivity, structure of the ecosystems, input supplies, availability and prices, and product prices). ${ }^{167-169}$ However, the uncertainty of external input supplies and global warming will probably be the most determining parameters on the future of aquaculture. In this regard, the sustainability of aquaculture industry will likely require an adaptation to predicted climate change, in addition to appropriate mitigation measures.

\section{1 | Uncertainty of external input supplies}

The impact of climate change on capture fisheries will significantly affect fishmeal (FM) and fish oil (FO) supplies, prices and sustainability. In fact, the supply of FM and FO has already been declining in recent years, whereas their prices have sharply increased. FM and FO have traditionally been used as major nutritional inputs in aquaculture, especially for marine species, which require high levels of these two sources. However, the global shortage in their supply and continuous increase in their prices are a serious challenge facing aquaculture industry worldwide. As a result, the potential of plant proteins and oils (mainly oilseeds) in aquafeeds has been accelerating. Substantial amounts of research have been carried out on partial or total substitution of FM and FO with plant-based sources. ${ }^{170,171}$

It is likely from the above prediction that the use of FM and FO in fish feeds will decline significantly. Consequently, the requirements for VE will likely change. It is well documented that VE requirements increase at high levels of dietary n-3 PUFA (eg fish oil). In light of the expected heavy inclusion of plant proteins and oils ( $n-6$ PUFA) in fish feeds, possibly lower dietary VE levels would be required to optimize fish performance and prevent lipid peroxidation. ${ }^{25}$ The fish requirements for other micronutrients which are interacting with VE, such as Se and VC, may also change. This simply means that considerable attention in the future research must be directed to reevaluation of these micronutrients, in light of the expected plant-based aquafeed formulations.

\subsection{Impact of climate change}

The increase or decrease in water temperature, as a result of climate change, may also affect the VE requirement and metabolism in farmed fish. Fish can adapt to cold temperatures by biochemical regulation of membrane bilayer fluidity, which is essential for cellular function at low temperatures. ${ }^{37,38}$ Under such conditions, membrane homeostasis is secured by the production of high levels of low molecular weight, unsaturated fatty acids in cellular membrane lipids. ${ }^{37,39}$ High lipid unsaturation would render cellular membranes vulnerable to oxidative damage, which can impair cellular functions. This means that VE may play a significant role as an antioxidant, to combat the expected cellular damage at low temperature. In support, Gieseg, Cuddihy, Hill and Davison ${ }^{172}$ found that Antarctic fish had plasma VE concentrations five to six times higher than in temperate water fish species, suggesting that Antarctic fish may be exposed to greater metabolic stress than temperate species. This indicates that VE may be required at greater amounts in cold-exposed fish species than in tropical or temperate species. However, these requirements will likely be species-specific and will also depend on the degree of coldness. Further research is needed to explore and clarify the relationship between dietary VE and cold stress.

Similarly, increasing environmental temperatures may modulate the VE requirements and metabolism. In land animals, for example, high temperature reduces the serum concentrations of vitamins, including VE and micro minerals. ${ }^{173}$ Since VE is considered the first defence line against lipid peroxidation caused by heat stress, higher dietary levels of this micronutrient, together with other vitamins and minerals, are recommended under heat stress. ${ }^{173,174}$ Nonetheless, the $\mathrm{VE}$ requirements and the metabolism of farmed fish in response to heat stress are not well investigated. Only Chen, Lochmann, Goodwin, Praveen, Dabrowski and Lee ${ }^{41}$ reported that dietary VC and VE significantly affected the response of juvenile golden shiner (Notemigonus crysoleucas) to heat stress. When the fish were fed a VE-deficient diet and exposed to stressful water temperatures $\left(36-37.8^{\circ} \mathrm{C}\right)$, they exhibited lower visceral VE concentrations, haematological parameters, alternative complement activity ( $\mathrm{ACH} 50)$ and survival than those fed VE-supplemented diets. This particular study suggests that fish, like land animals, may require higher dietary VE when exposed to heat stress. However, further research is needed to support this assumption. It is evident from the above 
discussion that future research will have to reconsider the VE requirements of farmed fish under the expected heat or cold stresses, resulting from the changes in weather temperature.

\section{7 | CONCLUSION}

Vitamin $E(V E)$ is composed of a group of fat-soluble molecules, from which $\alpha$-tocopherol is the most active homologous. It is a structural component of cell membranes with a potent chain-breaking antioxidant action, which plays a main role in several biological processes. VE performs many functions in farmed fish, including prevention of peroxidation of cellular and subcellular membrane phospholipids and leading to maintaining the structural and functional integrity of animal cells, improvement of the immune response, enhancing growth performance and feed efficiency, preventing muscle degeneration, reducing the risk of atherosclerosis, interaction with a number of micronutrients especially VC and Se, improving reproductive efficiency and larval performance, and improving meat quality and shelf life of seafood. However, the role of VE as strong, fat-soluble antioxidant against lipid peroxidation remains the most investigated function.

The effects of VE depend on fish species and size, VE dose, lipid composition (polyunsaturated fatty acids; PUFA), presence or absence of other micronutrients, such as VC and Se. Generally speaking, marine fish require higher VE for lipid peroxidation protection and growth promotion than freshwater fish. Also, early life stages may require higher VE levels than latter grow-out stages. VE, VC and Se also act synergistically and can spare the metabolic requirements of one another.

The aquaculture sustainability, especially the certainty of external feed input supplies and environmental conditions (such as water temperature and salinity), will likely be affected by climate change. For example, fish meal (FM) and fish oil (FO), which have traditionally been used as major nutritional inputs in aquaculture, will be (and have already been) seriously affected by climate change, leading to global shortage in their supply and increase in their prices. Therefore, the requirements of farmed fish for dietary FM and FO should be reconsidered, whereas searching for FM and FO potential replacers must be encouraged. Plant protein and oil sources (such as oilseeds) are an ideal candidate to fill this predicted gap. The use of these sources in aquafeeds has already been escalating. Consequently, the requirements for VE will have to be reevaluated. The fish requirements for other micronutrients which act synergistically with VE, such as Se and VC, should also be reconsidered. In light of the expected heavy inclusion of these plant protein and oil sources in fish feeds, lower dietary VE levels may possibly be required to optimize fish performance and prevent lipid peroxidation. However, more research is needed to support this assumption.

Heat and cold stresses, resulting from climate change, affect the VE metabolism and, in turn modulate the VE requirement, in land animals. Higher levels of dietary VE (and other vitamins and minerals) have been recommended under heat stress. However, the VE requirement and metabolism of farmed fish in response to high or low temperatures are not well investigated. Farmed fish may require higher dietary VE when exposed to heat or cold stresses, but this assumption requires further investigations. Generally speaking, future research should reconsider the VE requirements of farmed fish under the uncertainty of feed input supplies and the expected heat or cold stresses, resulting from the impacts of climate changes.

\section{ACKNOWLEDGEMENTS}

None.

\section{DATA AVAILABILITY STATEMENT}

Data sharing not applicable - no new data generated.

\section{ORCID}

Abdel-Fattah M. El-Sayed (D) https://orcid. org/0000-0003-3378-1205

\section{REFERENCES}

1. NRC (National Research Council). Nutrient Requirements of Fish and Shrimp. National Academies Press; 2011.

2. Azzi A. The role of alpha-tocopherol in preventing disease. Eur $J$ Nutr. 2004;43:18-25.

3. Hamre K. Metabolism, interactions, requirements and functions of vitamin E in fish. Aquacult Nutr. 2011;17(1):98-115. https://doi. org/10.1111/j.1365-2095.2010.00806.x

4. Izquierdo M, Betancor M. Vitamin E. In: Lee C-S, Lim C, Gatlin DM, Webster C, eds. Dietary Nutrients, Additives and Fish Health (1st edn). John Wiley \& Sons, Inc., 2015:173-193.

5. Wu JH, Croft KD. Vitamin E metabolism. Mol Aspects Med. 2007;28(5-6):437-452.https://doi.org/10.1016/j.mam.2006.12.007.

6. Repetto $M$, Semprine J, Boveris A. Lipid peroxidation: chemical mechanism, biological implications and analytical determination. In: Catala V, ed. Lipid Peroxidation. InTech, 2012:1-30.

7. Afonso C, Bandarra NM, Nunes L, Cardoso C. Tocopherols in seafood and aquaculture products. Crit Rev Food Sci Nutr. 2016;56(1):128-140. https://doi.org/10.1080/10408 398.2012.694920

8. Amaral $A B$, Silva MVD, Lannes SC. Lipid oxidation in meat: mechanisms and protective factors - a review. Food Sci Technol. 2018;38(suppl 1):1-15. https://doi.org/10.1590/fst.32518

9. Mourente G, Bell JG, Tocher DR. Does dietary tocopherol level affect fatty acid metabolism in fish? Fish Physiol Biochem. 2007;33(3):269-280. https://doi.org/10.1007/s10695-007-9139-4

10. Huang $\mathrm{CH}$, Higgs DA, Balfry SK, Devlin RH. Effect of dietary vitamin $\mathrm{E}$ level on growth, tissue lipid peroxidation, and erythrocyte fragility of transgenic coho salmon, Oncorhynchus kisutch. Comp Biochem Physiol A Mol Integr Physiol. 2004;139(2):199-204. https:// doi.org/10.1016/j.cbpb.2004.09.001

11. Merel S, Walker D, Chicana R, Snyder S, Baurès E, Thomas O. State of knowledge and concerns on cyanobacterial blooms and cyanotoxins. Environ Int. 2013;59:303-327.

12. Amado LL, Monserrat JM. Oxidative stress generation by microcystins in aquatic animals: why and how. Environ Int. 2010;36(2):226235. https://doi.org/10.1016/j.envint.2009.10.010

13. Li B, Li Z, Sun Y, Wang S, Huang B, Wang J. Effects of dietary lysolecithin (LPC) on growth, apparent digestibility of nutrient and lipid metabolism in juvenile turbot Scophthalmus maximus L. Aquacult Fish. 2019;4(2):61-66. https://doi.org/10.1016/j.aaf.2018.11.003

14. Prieto A, Jos A, Pichardo S, Moreno I, Cameán A. Protective role of vitamin $E$ on the microcystin-induced oxidative stress in tilapia fish (Oreochromis niloticus). Environ Toxicol Chem. 2008;27:1152-1159

15. Sevcikova M, Modra H, Slaninova A, Svobodova Z. Metals as a cause of oxidative stress in fish: a review. Vet Med (Praha). 2011;56:537-546. 
16. Hassaan MS, Goda AMAS, Mahmoud SA, Tayel SI. Protective effect of dietary vitamin $E$ against fungicide copperoxychloride stress on Nile tilapia, Oreochromis niloticus (L.) fingerlings. Int Aquat Res. 2014;6(1):1-15. https://doi.org/10.1007/s40071-014-0058-6

17. Wu F, Jiang $M$, Wen $\mathrm{H}$, et al. Dietary vitamin $\mathrm{E}$ effects on growth, fillet textural parameters, and antioxidant capacity of genetically improved farmed tilapia (GIFT), Oreochromis niloticus. Aquacult Int. 2017;25(2):991-1003. https://doi.org/10.1007/s1049 9-016-0089-7

18. Li J, Liang X-F, Tan Q, et al. Effects of vitamin E on growth performance and antioxidant status in juvenile grass carp Ctenopharyngodon idellus. Aquaculture. 2014;430:21-27. https:// doi.org/10.1016/j.aquaculture.2014.03.019

19. Lu $Y$, Liang $X-P$, Jin $M$, et al. Effects of dietary vitamin $E$ on the growth performance, antioxidant status and innate immune response in juvenile yellow catfish (Pelteobagrus fulvidraco). Aquaculture. 2016;464:609-617. https://doi.org/10.1016/j.aquac ulture.2016.08.009

20. Li S, Lian X, Chen N, Wang M, Sang C. Effects of dietary vitamin E level on growth performance, feed utilization, antioxidant capacity and nonspecific immunity of largemouth bass, Micropterus salmoides. Aquacult Nutr. 2018;24(6):1679-1688. https://doi. org/10.1111/anu.12802

21. Kim K, Wang X, Choi S, Park G, Koo J, Bai S. No synergistic effects by the dietary supplementation of ascorbic acid, $\alpha$-tocopheryl acetate and selenium on the growth performance and challenge test of Edwardsiella tarda in fingerling Nile tilapia, Oreochromis niloticus L. Aquacult Res. 2003;34:1053-1058.

22. Tocher D, Mourente G, Van der Eecken A, Evjemo J, Diaz E, Wille M. Comparative study of antioxidant defence mechanisms in marine fish fed variable levels of oxidised oil and vitamin E. Aquacult Int. 2003;11:195-216.

23. Zheng K, Zhu X, Han D, Yang Y, Lei W, Xie S. Effects of dietary lipid levels on growth, survival and lipid metabolism during early ontogeny of Pelteobagrus vachelli larvae. Aquaculture. 2010;299:121-127.

24. Shahkar E, Hamidoghli A, Yun H, Kim D-J, Bai SC. Effects of dietary vitamin $\mathrm{E}$ on hematology, tissue $\alpha$-tocopherol concentration and non-specific immune responses of Japanese eel, Anguilla japonica. Aquaculture. 2018;484:51-57. https://doi.org/10.1016/j.aquac ulture.2017.10.036

25. Faizan $M$, Stubhaug I, Menoyo D, Esatbeyoglu T, Wagner $A$, Struksnæs G. Dietary alpha-tocopherol affects tissue vitamin E and malondialdehyde levels but does not change antioxidant enzymes and fatty acid composition in farmed Atlantic salmon (Salmo salar L.). Int J Vitam Nutr Res. 2013;83:238-245.

26. Lygren B, Hjeltnes B, Waagbø R. Immune response and disease resistance in Atlantic salmon (Salmo salar L.) fed three levels of dietary vitamin $E$ and the effect of vaccination on the liver status of antioxidant vitamins. Aquacult Int. 2001;9:401-411.

27. Bell J, McEvoy J, Tocher D, Sargent J. Depletion of $\alpha$-tocopherol and astaxanthin in Atlantic salmon (Salmo salar) affects autoxidative defense and fatty acid metabolism. J Nutr. 2000;130:1800-1808.

28. Mansour N, McNiven M, Richardson G. The effect of dietary supplementation with blueberry, $\alpha$-tocopherol or astaxanthin on oxidative stability of Arctic char (Salvelinus alpinus) semen. Theriogenology. 2006;66:373-382.

29. Izquierdo $M$, Domínguez $D$, Jiménez Jl, et al. Interaction between taurine, vitamin $\mathrm{E}$ and vitamin $\mathrm{C}$ in microdiets for gilthead seabream (Sparus aurata) larvae. Aquaculture. 2019;498:246-253. https://doi.org/10.1016/j.aquaculture.2018.07.010

30. Atalah E, Hernández-Cruz CM, Ganga R, et al. Enhancement of gilthead seabream (Sparus aurata) larval growth by dietary vitamin $E$ in relation to two different levels of essential fatty acids. Aquacult Res. 2012;43(12):1816-1827. https://doi. org/10.1111/j.1365-2109.2011.02989.x
31. Betancor MB, Atalah E, Caballero M, et al. $\alpha$-Tocopherol in weaning diets for European sea bass (Dicentrarchus labrax) improves survival and reduces tissue damage caused by excess dietary DHA contents. Aquacult Nutr. 2011;17(2):e112-e122. https://doi. org/10.1111/j.1365-2095.2009.00741.x

32. Izquierdo MS, Scolamacchia M, Betancor M, et al. Effects of dietary DHA and alpha-tocopherol on bone development, early mineralisation and oxidative stress in Sparus aurata (Linnaeus, 1758) larvae. Br J Nutr. 2013;109:1796-1805.

33. Montero D, Marrero M, Izquierdo M, Robaina L, Vergara J, Tort L. Effect of vitamin $E$ and $C$ dietary supplementation on some immune parameters of gilthead seabream (Sparus aurata) juveniles subjected to crowding stress. Aquaculture. 1999;171:269-278.

34. Lozano AR, Borges P, Robaina L, et al. Effect of different dietary vitamin $E$ levels on growth, fish composition, fillet quality and liver histology of meagre (Argyrosomus regius). Aquaculture. 2017;468:175-183. https://doi.org/10.1016/j.aquac ulture.2016.10.006

35. Ruiz MA, Betancor MB, Robaina L, et al. Dietary combination of vitamin $\mathrm{E}, \mathrm{C}$ and $\mathrm{K}$ affects growth, antioxidant activity, and the incidence of systemic granulomatosis in meagre (Argyrosomus regius). Aquaculture. 2019;498:606-620. https://doi.org/10.1016/j. aquaculture.2018.08.078

36. Ruiz MA, Hernández-Cruz CM, Caballero MJ, et al. Appearance of systemic granulomatosis is modulated by the dietary supplementation of vitamin $\mathrm{E}$ and $\mathrm{C}$ in meagre (Argyrosomus regius) larvae fed inert microdiets. Aquaculture. 2019;506:139-147. https://doi. org/10.1016/j.aquaculture.2019.03.032

37. Crockett EL. The cold but not hard fats in ectotherms: consequences of lipid restructuring on susceptibility of biological membranes to peroxidation, a review. J Comp Physiol B. 2008;178:795-809.

38. Fujisawa A, Dunlap WC, Yamamoto Y. Vitamin E protection in the biochemical adaptation of marine organisms to coldwater environments. Comp Biochem Physiol Part B, Biochem Mol Biol. 2010;157(2):145-158. https://doi.org/10.1016/j. cbpb.2010.04.011

39. Hazel JR, Williams EE. The role of alterations in membrane lipid composition in enabling physiological adaptations of marine organisms to their physical environment. Prog Lipid Res. 1990;29:167-227.

40. Cowey C, Degener E, Tacon A, Youngson A, Bell J. The effects of vitamin $E$ and oxidized fish oil on the nutrition of rainbow trout (Salmo gairdneri) grown at natural, varying water temperature. $\mathrm{Br} J$ Nutr. 1984;51:443-451.

41. Chen R, Lochmann R, Goodwin A, Praveen K, Dabrowski K, Lee $\mathrm{K}-\mathrm{J}$. Effects of dietary vitamins $\mathrm{C}$ and $\mathrm{E}$ on alternative complement activity, hematology, tissue composition, vitamin concentrations and response to heat stress in juvenile golden shiner (Notemigonus crysoleucas). Aquaculture. 2004;242(1-4):553-569. https://doi. org/10.1016/j.aquaculture.2004.09.012

42. Abdel-Ghany HM, El-Sayed A-FM, Ezzat AA, Essa MA, Helal AM. Dietary lipid sources affect cold tolerance of Nile tilapia (Oreochromis niloticus). J Therm Biol. 2019;79:50-55.

43. Abdel-Ghany H, Salem ME-S, Ezzat A, et al. Effects of different levels of dietary lipid on growth performance, liver histology and cold tolerance of Nile tilapia (Oreochromis niloticus). J Therm Biol. 2021;96:102833

44. Liu H-P, Wen B, Chen Z-Z, et al. Effects of dietary vitamin C and vitamin $E$ on the growth, antioxidant defence and digestive enzyme activities of juvenile discus fish (Symphysodon haraldi). Aquacult Nutr. 2019;25(1):176-183. https://doi.org/10.1111/anu.12841

45. Chen Y, Liu Y, Tian L, Niu J, Liang G, Yang H. Effect of dietary vitamin $E$ and selenium supplementation on growth, body composition, and antioxidant defense mechanism in juvenile largemouth 
bass (Micropterus salmoide) fed oxidized fish oil. Fish Physiol Biochem. 2013;39:593-604.

46. Asaikkutti A, Bhavan P, Vimala K, Karthik M, Cheruparambath P. Effect of different levels dietary vitamin $C$ on growth performance, muscle composition, antioxidant and enzyme activity of freshwater prawn, Macrobrachium malcolmsonii. Aquacult Rep. 2016;3:229-236.

47. Dawood MAO, Koshio S. Vitamin C supplementation to optimize growth, health and stress resistance in aquatic animals. Rev Aquacul. 2018;10(2):334-350. https://doi.org/10.1111/raq.12163

48. Hu Y, Zhang J, He L, et al. Effects of dietary vitamin C on growth, antioxidant activity, and immunity in ricefield eel (Monopterus albus). J World Aquac Soc. 2019;51(1):159-170. https://doi. org/10.1111/jwas.12636

49. Huang Q, Zhang S, Du T, Yang Q, Chi S, Liu H. Effects of dietary vitamin $\mathrm{E}$ on growth, immunity and oxidation resistance related to the Nrf2/Keap1 signalling pathway in juvenile Sillago sihama. Anim Feed Sci Tech. 2020;262:114403.

50. Jiménez-Fernández $E$, Ponce $M$, Rodriguez-Rúa $A$, Zuasti $E$, Manchado M, Fernández-Díaz C. Effect of dietary vitamin C level during early larval stages in Senegalese sole (Solea senegalensis). Aquaculture. 2015;443:65-76.

51. Liang X, Li Y, Hou Y, Qiu H, Zhou Q. Effect of dietary vitamin C on the growth performance, antioxidant ability and innate immunity of juvenile yellow catfish (Pelteobagrus fulvidraco Richardson). Aquacult Res. 2017;48:149-160.

52. Sato M, Yoshinaka R, Ikeda S. Dietary ascorbic acid requirement of rainbow trout for growth and collagen formation. Bull Jap Soc Sci Fish. 1978;44:1029-1035.

53. Montero D, Tort L, Robaina L, Vergara JM, Izquierdo MS. Low vitamin $\mathrm{E}$ in diet reduces stress resistance of gilthead seabream (Sparus aurata) juveniles. Fish Shellfish Immunol. 2001;11(6):473490. https://doi.org/10.1006/fsim.2000.0324

54. Ortuño J, Esteban MA, Meseguer J. The effect of dietary intake of vitamins $C$ and $E$ on the stress response of gilthead seabream (Sparus aurata L.). Fish \& Shellfish Immunology. 2003;14(2):145-156. https://doi.org/10.1006/fsim.2002.0428

55. Ortuño J, Cuesta A, Esteban M, Meseguer J. Effect of oral administration of high vitamin $C$ and $E$ dosages on the gilthead seabream (Sparus aurata L.) innate immune system. Vet Immunol Immunopathol. 2001;79:167-180.

56. Yildirim-Aksoy $\mathrm{M}$, Lim C, Li MH, Klesius $\mathrm{PH}$. Interaction between dietary levels of vitamins $C$ and $E$ on growth and immune responses in channel catfish, Ictalurus punctatus (Rafinesque). Aquacult Res. 2008;39(11):1198-1209. https://doi. org/10.1111/j.1365-2109.2008.01984.x

57. Lim C, Yildirim-Aksoy M, Shelby R, Li MH, Klesius PH. Growth performance, vitamin $\mathrm{E}$ status, and proximate and fatty acid composition of channel catfish, Ictalurus punctatus, fed diets containing various levels of fish oil and vitamin E. Fish Physio Biochem. 2010;36(4):855-866. https://doi.org/10.1007/s1069 5-009-9360-4

58. Gao J, Koshio S, Ishikawa M, Yokoyama S, Mamauag REP, Han Y. Effects of dietary oxidized fish oil with vitamin E supplementation on growth performance and reduction of lipid peroxidation in tissues and blood of red sea bream Pagrus major. Aquaculture. 2012;357:73-79. https://doi.org/10.1016/j.aquac ulture.2012.05.034

59. Hamre K, Lie $\varnothing$. Retained levels of dietary $\alpha$-, $\gamma$-and $\delta$-tocopherol in tissues and body fluids of Atlantic salmon, Salmo salar. L. Aquacult Nutr. 1997;3:99-107.

60. Hamre K, Waagbø R, Berge R, Lie $\varnothing$. Vitamins $C$ and $E$ interact in juvenile Atlantic salmon (Salmo salar, L.). Free Radic Biol Med. 1997;22:137-149.

61. Wahli T, Verlhac V, Gabaudan J, Schüep W, Meier W. Influence of combined vitamins $\mathrm{C}$ and $\mathrm{E}$ on non-specific immunity and disease resistance of rainbow trout, Oncorhynchus mykiss (Walbaum). J Fish Dis. 1998;21:127-137.

62. Lim C, Yildirim-Aksoy M, Li MH, Welker TL, Klesius PH. Influence of dietary levels of lipid and vitamin $\mathrm{E}$ on growth and resistance of Nile tilapia to Streptococcus iniae challenge. Aquaculture. 2009;298(1-2):76-82. https://doi.org/10.1016/j.aquac ulture.2009.09.025

63. Lee K-J, Dabrowski K. Long-term effects and interactions of dietary vitamins $C$ and $E$ on growth and reproduction of yellow perch, Perca flavescens. Aquaculture. 2004;230(1-4):377-389. https://doi.org/10.1016/s0044-8486(03)00421-6

64. Moreau R, Dabrowski K, Czesny S, Cihla F. Vitamin C-vitamin $\mathrm{E}$ interaction in juvenile lake sturgeon (Acipenser fulvescens R.), a fish able to synthesize ascorbic acid. J Appl Ichthyol. 1999;15:250-257.

65. Gao J, Koshio S, Ishikawa M, Yokoyama S, Mamauag R. Interactive effects of vitamin $C$ and $E$ supplementation on growth performance, fatty acid composition and reduction of oxidative stress in juvenile Japanese flounder Paralichthys olivaceus fed dietary oxidized fish oil. Aquaculture. 2014;422:84-90.

66. Sies H. Oxidative stress: oxidants and antioxidants. Exp Physiol. 1997;82:291-295.

67. Arrigoni O, De Tullio M. Ascorbic acid: much more than just an antioxidant. Biochim Biophys Acta. 2002;1569:1-9.

68. Shiau S, Hsu C. Vitamin E sparing effect by dietary vitamin $C$ in juvenile hybrid tilapia, Oreochromis niloticus $\times 0$. aureus. Aquaculture. 2002;210:335-342.

69. Wilson R, Bowser P, Poe W. Dietary vitamin E requirement of fingerling channel catfish. J Nutr. 1984;114:2053-2058.

70. Gatlin D, Poe W, Wilson R, Ainsworth A, Bowser P. Effects of stocking density and vitamin $\mathrm{C}$ status on vitamin $\mathrm{E}$-adequate and vitamin E-deficient fingerling channel catfish. Aquaculture. 1986;56:187-195.

71. Betancor MB, Caballero MJ, Terova G, et al. Vitamin C enhances vitamin $\mathrm{E}$ status and reduces oxidative stress indicators in sea bass larvae fed high DHA microdiets. Lipids. 2012;47(12):1193-1207. https://doi.org/10.1007/s11745-012-3730-x

72. Ji H, Om A, Yoshimatsu T, Hayashi M, Umino T, Nakagawa $H$. Effect of dietary vitamins $C$ and $E$ fortification on lipid metabolism in red sea bream Pagrus major and black sea bream Acanthopagrus schlegeli. Fish Sci. 2003;69:1001-1009.

73. Lovell R, Miyazaki T, Rabegnator S. Requirement for $\alpha$-tocopherol by channel catfish fed diets low in polyunsaturated triglycerides. $J$ Nutr. 1984;114:894-901.

74. Frischknecht R, Wahli T, Meier W. Comparison of pathological changes due to deficiency of vitamin $\mathrm{C}$, vitamin $\mathrm{E}$, and combinations of vitamin $\mathrm{C}$ and $\mathrm{E}$ in rainbow trout, Oncorhynchus mykiss (Walbaum). J Fish Dis. 1994;17:31-45.

75. Hamre K, Sissener NH, Lock EJ, et al. Antioxidant nutrition in Atlantic salmon (Salmo salar) parr and post-smolt, fed diets with high inclusion of plant ingredients and graded levels of micronutrients and selected amino acids. PeerJ. 2016;4:e2688. https://doi. org/10.7717/peerj.2688

76. Lim C, Yildirim-Aksoy M, Welker T, Klesius P, Li M. Growth performance, immune response, and resistance to Streptococcus iniae of Nile tilapia, Oreochromis niloticus, fed diets containing various levels of vitamins C and E. J World Aquac Soc. 2010;41:35-48.

77. Li M, Li E, Qin J, et al. Growth, immune response and resistance to Aeromonas hydrophila of darkbarbel catfish Pelteobagrus vachelli fed diets with different linolenic acids, vitamins $C$ and $E$ levels. Aquacult Nutr. 2016;22:664-674.

78. Li M, Chen L, Qin J, Li E, Yu N, Du Z. Growth performance, antioxidant status and immune response in darkbarbel catfish Pelteobagrus vachelli fed different PUFA/vitamin E dietary levels and exposed to high or low ammonia. Aquaculture. 2013;406:18-27.

79. Frankel E. Lipid Oxidation. The Oily Press; 1998:303. 
80. Frankel E. Recent advances in lipid oxidation. J Sci Food Agric. 1991;54:495-511.

81. Evarts R, Bieri J. Ratios of polyunsaturated fatty acids to $\alpha$ tocopherol in tissues of rats fed corn or soybean oils. Lipids. 1974;9:860-864.

82. Azzi A, Stocker A. Vitamin E: non-antioxidant roles. Prog Lipid Res. 2000;39:231-255.

83. Roem A, Kohler C, Stickney R. Vitamin E requirements of the blue tilapia, Oreochromis aureus (Steindachner), in relation to dietary lipid level. Aquaculture. 1990;87:155-164.

84. Lin Y-H, Shiau S-Y. Dietary vitamin E requirement of grouper, Epinephelus malabaricus, at two lipid levels, and their effects on immune responses. Aquaculture. 2005;248(1-4):235-244. https:// doi.org/10.1016/j.aquaculture.2005.04.020

85. Schwarz F, Kirchgessner M, Steinhart H, Runge G. Influence of different fats with varying additions of $\alpha$-tocopheryl acetate on growth and body composition of carp (Cyprinus carpio L.) Aquaculture. 1988;69:57-67.

86. Kanazawa K. Hepatotoxicity caused by dietary secondary products originating from lipid peroxidation. In: Friedman M, ed. Nutritional and Toxicology Consequences of Food Processing. Plenum; 1991:237-253.

87. Kanazawa K. Tissue injury induced by dietary products of lipid peroxidation. In: Corongiu F, ed. Free Radicals and Antioxidants in Nutrition. Richelieu Press; 1993:383-399.

88. Peng S, Chen L, Qin JG, et al. Effects of dietary vitamin E supplementation on growth performance, lipid peroxidation and tissue fatty acid composition of black sea bream (Acanthopagrus schlegeli) fed oxidized fish oil. Aquacult Nutr. 2009;15(3):329-337. https:// doi.org/10.1111/j.1365-2095.2009.00657.x

89. Lewis-McCrea L, Lall S. Effects of moderately oxidized dietary lipid and the role of vitamin $\mathrm{E}$ on the development of skeletal abnormalities in juvenile Atlantic halibut (Hippoglossus hippoglossus). Aquaculture. 2007;262:142-155.

90. Martins D, Afonso L, Hosoya S, Lewis-McCrea L, Valente L, Lall S. Effects of moderately oxidized dietary lipid and the role of vitamin E on the stress response in Atlantic halibut (Hippoglossus hippoglossus L.). Aquaculture. 2007;272:573-580.

91. Hang T. Effects of Dietary Oxidation Status and Vitamin E Level on Performance, Fillet Quality and Robustness to Acute Stress in Atlantic salmon (Salmo salar L.). Master's thesis. Norwegian University of Life Sciences; 2011:54.

92. Baker R, Davies S. Modulation of tissue $\alpha$-tocopherol in African catfish, Clarias gariepinus (Burchell), fed oxidized oils, and the compensatory effect of supplemental dietary vitamin E. Aquacult Nutr. 1997;3:91-97.

93. Zhong Y, Lall S, Shahidi F. Effects of oxidized dietary oil and vitamin $E$ supplementation on lipid profile and oxidation of muscle and liver of juvenile Atlantic cod (Gadus morhua). J Agric Food Chem. 2007;55:6379-6386

94. Lall S, Parazo M. Vitamins in fish and shellfish. In: Ruiter A, ed. Fish and Fishery Product: Composition, Nutritive Properties and Stability. CAB International; 1995:157-186.

95. Huang $\mathrm{C}-\mathrm{H}$, Huang S-L. Effect of dietary vitamin $\mathrm{E}$ on growth, tissue lipid peroxidation, and liver glutathione level of juvenile hybrid tilapia, Oreochromis niloticus $\times 0$. aureus, fed oxidized oil. Aquaculture. 2004;237(1-4):381-389. https://doi.org/10.1016/j. aquaculture.2004.04.002

96. Mourente G, Dıaz-Salvago E, Bell J, Tocher D. Increased activities of hepatic antioxidant defence enzymes in juvenile gilthead sea bream (Sparus aurata L.) fed dietary oxidised oil: attenuation by dietary vitamin E. Aquaculture. 2002;214:343-361.

97. Ursini F. Antioxidant activity of selenium dependent peroxidases: the molecular basis of the synergistic effect between selenium and vitamin E. In: Diplock AT, Gutteridge JM, Shukla VK, Pryor
WA, eds. Antioxidants, Free Radicals and Polyunsaturated Fatty Acids in Biology and Medicine. International Food Science Centre A/S; 1993:105-109.

98. Naderi M, Keyvanshokooh S, Salati AP, Ghaedi A. Effects of dietary vitamin $E$ and selenium nanoparticles supplementation on acute stress responses in rainbow trout (Oncorhynchus mykiss) previously subjected to chronic stress. Aquaculture. 2017;473:215222. https://doi.org/10.1016/j.aquaculture.2017.02.020

99. Naderi M, Keyvanshokooh S, Salati AP, Ghaedi A. Combined or individual effects of dietary vitamin $\mathrm{E}$ and selenium nanoparticles on humoral immune status and serum parameters of rainbow trout (Oncorhynchus mykiss) under high stocking density. Aquaculture. 2017;474:40-47. https://doi.org/10.1016/j.aquaculture.2017.03.036

100. Naderi M, Keyvanshokooh S, Salati AP, Ghaedi A. Proteomic analysis of liver tissue from rainbow trout (Oncorhynchus mykiss) under high rearing density after administration of dietary vitamin $E$ and selenium nanoparticles. Comp Biochem Physiol Part D Genom Prot. 2017;22:10-19. https://doi.org/10.1016/j.cbd.2017.02.001

101. Naderi M, Keyvanshokooh S, Ghaedi A, Salati AP. Interactive effects of dietary Nano selenium and vitamin $E$ on growth, haematology, innate immune responses, antioxidant status and muscle composition of rainbow trout under high rearing density. Aquacult Nutr. 2019;25(5):1156-1168. https://doi.org/10.1111/anu.12931

102. Lin Y-H, Shiau S-Y. Mutual sparing of dietary requirements for alpha-tocopherol and selenium in grouper, Epinephelus malabaricus. Aquaculture. 2009;294(3-4):242-245. https://doi.org/10.1016/j. aquaculture.2009.06.002

103. Le KT, Fotedar R, Partridge G. Selenium and vitamin E interaction in the nutrition of yellowtail kingfish (Seriola lalandi): physiological and immune responses. Aquacult Nutr. 2014;20(3):303-313. https://doi.org/10.1111/anu.12079

104. Le KT, Dao TTT, Fotedar R, Partrigde GJ. Effects of variation in dietary contents of selenium and vitamin $\mathrm{E}$ on growth and physiological and haematological responses of yellowtail kingfish, Seriola lalandi. Aquacult Int. 2013;22(2):435-446. https://doi. org/10.1007/s10499-013-9651-8

105. Dawood M, Zommara M, Eweedah N, Helal A. Synergistic effects of selenium nanoparticles and vitamin $\mathrm{E}$ on growth, immune-related gene expression, and regulation of antioxidant status of Nile tilapia (Oreochromis niloticus). Biol Trace Elem Res. 2020;195(2):624-635. https://doi.org/10.1007/s12011-019-01857-6

106. Jaramillo F Jr, Peng LI, Gatlin lii DM. Selenium nutrition of hybrid striped bass (Morone chrysops $\times$ M. saxatilis) bioavailability, toxicity and interaction with vitamin E. Aquacult Nutr. 2009;15(2):160-165. https://doi.org/10.1111/j.1365-2095.2008.00579.x

107. Bell J, Cowey C, Adron J, Pirie B. Some effects of selenium deficiency on enzyme activities and indices of tissue peroxidation in Atlantic salmon parr (Salmo salar). Aquaculture. 1987;65:43-54.

108. Bell J, Cowey C, Adron J, Shanks A. Some effects of vitamin E and selenium deprivation on tissue enzyme levels and indices of tissue peroxidation in rainbow trout (Salmo gairdneri). Br J Nutr. 1985;53:149-157.

109. Bell J, Pirie B, Adron J, Cowey C. Some effects of selenium deficiency on glutathione peroxidase (EC 1.11. 1.9) activity and tissue pathology in rainbow trout (Salmo gairdneri). $\mathrm{Br} J$ Nutr. 1986;55:305-311.

110. Harsij M, Gholipour Kanani H, Adineh H. Effects of antioxidant supplementation (nano-selenium, vitamin $\mathrm{C}$ and $\mathrm{E}$ ) on growth performance, blood biochemistry, immune status and body composition of rainbow trout (Oncorhynchus mykiss) under sub-lethal ammonia exposure. Aquaculture. 2020;521:734942. https://doi. org/10.1016/j.aquaculture.2020.734942

111. Kocabas A, Gatlin DI. Dietary vitamin E requirement of sunshine bass (Morone chrysops female x M. saxatilis male). Aquacult Nutr. 1999;5:3-7. 
112. Nogala-Kałucka ME. Fat-soluble vitamins. In: Sikorski ZE, Kołakowska A, eds. Chemical and Functional Properties of Food Lipids. CRC Press; 2003:109-132.

113. Gaylord G. Re-evaluation of vitamin E supplementation of practical diets for channel catfish, Ictalurus punctatus, production. Aquacult Nutr. 1998;4:109-114

114. Ng W, Wang Y, Ketchimenin P, Yuen K. Replacement of dietary fish oil with palm fatty acid distillate elevates tocopherol and tocotrienol concentrations and increases oxidative stability in the muscle of African catfish, Clarias gariepinus. Aquaculture. 2004;233:423-437.

115. Sharifzadeh SA, Khara $H$, Ghobadi S. Effects of vitamins $E$ and Riboflavin $\left(B_{2}\right)$ and combinations of them on the hematological parameters of common carp, Cyprinus carpio L., fingerlings. Arch Pol Fish. 2015;23(2):107-111. https://doi.org/10.1515/ aopf-2015-0012

116. Pan JH, Feng L, Jiang WD, et al. Vitamin E deficiency depressed fish growth, disease resistance, and the immunity and structural integrity of immune organs in grass carp (Ctenopharyngodon idella): Referring to NF-kappaB, TOR and Nrf2 signaling. Fish Shellfish Immunol. 2017;60:219-236. https://doi.org/10.1016/j. fsi.2016.11.044

117. Chaiyapechara S, Casten MT, Hardy RW, Dong FM. Fish performance, fillet characteristics, and health assessment index of rainbow trout (Oncorhynchus mykiss) fed diets containing adequate and high concentrations of lipid and vitamin E. Aquaculture. 2003;219(1-4):715-738. https://doi.org/10.1016/s0044 $-8486(03) 00025-5$

118. Trenzado CE, Morales AE, de la Higuera M. Physiological changes in rainbow trout held under crowded conditions and fed diets with different levels of vitamins $E$ and $C$ and highly unsaturated fatty acids (HUFA). Aquaculture. 2008;277(3-4):293-302. https://doi. org/10.1016/j.aquaculture.2008.02.031

119. Liu B, Xu P, Xie J, et al. Effects of emodin and vitamin E on the growth and crowding stress of Wuchang bream (Megalobrama amblycephala). Fish Shellfish Immunol. 2014;40(2):595-602. https:// doi.org/10.1016/j.fsi.2014.08.009

120. Gao J, Koshio S. Effect of dietary lipid oxidation with vitamin C and $\mathrm{E}$ supplementation on fillet quality of red sea bream, Pagrus major (Temminck \& Schlegel) during storage. Aquacult Res. 2015;46(10):2382-2391. https://doi.org/10.1111/are.12395

121. Trushenski JT, Kohler CC. Influence of stress, exertion, and dietary natural source vitamin e on prostaglandin synthesis, hematology, and tissue fatty acid composition of sunshine bass. N Am J Aquacult. 2007;70(2):251-265. https://doi.org/10.1577/a07-024.1

122. Lygren B, Hamre K, Waagbø R. Effect of induced hyperoxia on the antioxidant status of Atlantic salmon Salmo salar L. fed three different levels of dietary vitamin E. Aquacult Res. 2000;31:401-407.

123. Welker TL, Congleton JL. Oxidative stress in migrating spring chinook salmon smolts of hatchery origin: changes in vitamin $E$ and lipid peroxidation. Trans Am Fish Soc. 2005;134(6):1499-1508. https://doi.org/10.1577/t04-157.1

124. Dantagnan P, Gonzalez K, Hevia M, et al. Effect of the arachidonic acid/vitamin $E$ interaction on the immune response of juvenile Atlantic salmon (Salmo salar) challenged against Piscirickettsia salmonis. Aquacult Nutr. 2017;23(4):710-720. https://doi. org/10.1111/anu.12438

125. Zhou QC, Wang LG, Wang HL, Wang T, Elmada CZ, Xie FJ. Dietary vitamin E could improve growth performance, lipid peroxidation and non-specific immune responses for juvenile cobia (Rachycentron canadum). Aquacult Nutr. 2013;19(3):421-429. https://doi.org/10.1111/j.1365-2095.2012.00977.x

126. Moniruzzaman M, Park G, Yun H, Lee S, Park Y, Bai SC. Synergistic effects of dietary vitamin $E$ and selenomethionine on growth performance and tissue methylmercury accumulation on mercuryinduced toxicity in juvenile olive flounder, Paralichthys olivaceus
(Temminck et Schlegel). Aquacult Res. 2017;48(2):570-580. https:// doi.org/10.1111/are.12904

127. Kim M-S, Hur D-H, Lee S-M, Jeoung E, Jeong HD, Hong S. Effects of vitamin e with different levels or sources of dietary lipid on the growth and expression of inflammatory, oxidative stress, and apoptotic genes in the head kidney of olive flounder, Paralichthys olivaceus. J World Aquac Soc. 2017;48(3):518-530. https://doi. org/10.1111/jwas.12359

128. Wang Z, Mai K, Liufu Z, et al. Effect of high dietary intakes of vitamin $\mathrm{E}$ and $\mathrm{n}-3$ HUFA on immune responses and resistance to Edwardsiella tarda challenge in Japanese flounder (Paralichthys olivaceus, Temminck and Schlegel). Aquacult Res. 2006;37(7):681692. https://doi.org/10.1111/j.1365-2109.2006.01481.x

129. Jiang $M, M a L$, Shao $H$, et al. Dietary vitamin $E$ requirement of sub-adult genetically improved farmed tilapia strain of Nile tilapia (Oreochromis niloticus) reared in freshwater. Aquacult Nutr. 2020;26(2):233-241. https://doi.org/10.1111/anu.12983

130. Qiang J, Wasipe A, He J, et al. Dietary vitamin E deficiency inhibits fat metabolism, antioxidant capacity, and immune regulation of inflammatory response in genetically improved farmed tilapia (GIFT, Oreochromis niloticus) fingerlings following Streptococcus iniae infection. Fish Shellfish Immunol. 2019;92:395-404. https:// doi.org/10.1016/j.fsi.2019.06.026

131. Zhang Y, Li Y, Liang X, Gao J. Effects of dietary vitamin E supplementation on growth performance, fatty acid composition, lipid peroxidation and peroxisome proliferator-activated receptors (PPAR) expressions in juvenile blunt snout bream Megalobrama amblycephala. Fish Physiol Biochem. 2017;43(4):913-922. https:// doi.org/10.1007/s10695-016-0224-4

132. Sau SK, Paul BN, Mohanta KN, Mohanty SN. Dietary vitamin E requirement, fish performance and carcass composition of rohu (Labeo rohita) fry. Aquaculture. 2004;240(1-4):359-368. https:// doi.org/10.1016/j.aquaculture.2004.02.008

133. He M, Wang K, Liang X, Fang J, Geng Y, Chen Z. Effects of dietary vitamin $\mathrm{E}$ on growth performance as well as intestinal structure and function of channel catfish (Ictalurus punctatus, Rafinesque 1818). Exp Ther Med. 2017;14:5703-5710

134. Lu Y, Jin M, Yuan Y, Xiong J, Ma H, Zhou Q. Effects of different lipid sources on growth performance, body composition, the serum biochemical indices, fatty acids composition and antioxidant capacity in juvenile yellow catfish (Pelteobagrus fulvidraco). J Fish China. 2018:42:1094-1110.

135. Ma H, Jin M, Zhu T, et al. Effect of dietary arachidonic acid levels on growth performance, fatty acid profiles and lipid metabolism of juvenile yellow catfish (Pelteobagrus fulvidraco). Aquaculture. 2018;486:31-41.

136. Qiang J, Bao J, Tao Y, et al. CCD and RSM optimization approach for antioxidative activity and immune regulation in head kidney of yellow catfish (Pelteobagrus fulvidraco) based on different lipid levels and temperatures. Fish Shellfish Immunol. 2018;72:77-85.

137. Bae JY, Park GH, Yoo KY, Lee JY, Kim DJ, Bai SC. Evaluation of optimum dietary vitamin $\mathrm{E}$ requirements using $\mathrm{DL}$ - $\alpha$-tocopheryl acetate in the juvenile eel, Anguilla japonica. J Appl Ichthyol. 2013;29(1):213-217. https://doi.org/10.1111/jai.12001

138. Gatta P, Pirini M, Testi S, Vignola G, Monetti P. The influence of different levels of dietary vitamin $\mathrm{E}$ on sea bass Dicentrarchus labrax flesh quality. Aquacult Nutr. 2000;6:47-52.

139. Galaz G, Kim S, Lee K. Effects of different dietary vitamin E levels on growth performance, non-specific immune responses, and disease resistance against Vibrio anguillarum in parrot fish (Oplegnathus fasciatus). Asian-Australas J Anim Sci. 2010;23:916-623.

140. Ortuño J, Esteban MA, Meseguer J. High dietary intake of alphatocopherol acetate enhances the non-specific immune response of gilthead seabream (Sparus aurata L.). Fish Shellfish Immuno. 2000;10(4):293-307. https://doi.org/10.1006/fsim.1999.0238 
141. Pérez-Mateos M, Boyd L, Lanier T. Stability of omega-3 fatty acids in fortified surimi seafoods during chilled storage. J Agric Food Chem. 2004;52:7944-7949.

142. Kamireddy N, Jittinandana S, Kenney PB, et al. Effect of dietary vitamin $\mathrm{E}$ supplementation and refrigerated storage on quality of rainbow trout fillets. J Food Sci. 2011;76(4):S233-S241. https://doi. org/10.1111/j.1750-3841.2011.02121.x

143. Zuta P, Simpson B, Zhao X, Leclerc L. The effect of $\alpha$-tocopherol on the oxidation of mackerel oil. Food Chem. 2007;100:800-807.

144. Selmi S, Limam Z, Batista I, Bandarra N, Nunes M. Effects of storage temperature and $\alpha$-tocopherol on oil recovered from sardine mince. Int J Refrig. 2011;34:1315-1322.

145. Rodríguez A, Latorre M, Gajardo M, et al. Effect of the antioxidants composition in diet on the sensory and physical properties of frozen farmed Coho salmon (Oncorhynchus kisutch). J Sci Food Agric. 2015;95(6):1199-1206. https://doi.org/10.1002/jsfa.6808

146. Ruff N, Fitzgerald R, Cross T, Lynch A, Kerry J. Distribution of $\alpha-$ tocopherol in fillets of turbot (Scophthalmus maximus) and Atlantic halibut (Hippoglossus hippoglossus), following dietary $\alpha$-tocopheryl acetate supplementation. Aquacult Nutr. 2004;10:75-81.

147. Khalil A, Mansour E. Control of lipid oxidation in cooked and uncooked refrigerated carp fillets by antioxidant and packaging combinations. J Agric Food Chem. 1998;46:1158-1162.

148. Rudneva T II. Change in the activity of antioxidant enzymes in the process of early ontogenesis of various species of Black Sea fishes. Ukr Biokhim Zh. 1995;67:92-95.

149. Guerriero G, Ferro R, Russo GL, Ciarcia G. Vitamin E in early stages of sea bass (Dicentrarchus labrax) development. Comp Biochem Physiol. Part A: Mol Integ Physiol. 2004;138(4):435-439. https://doi. org/10.1016/j.cbpb.2004.06.003

150. Farris NW, Kim D, Hamidoghli A, et al. Dietary $\alpha$-Tocopheryl acetate and arachidonic acid synergistically improves superoxide dismutase activity in female Japanese eel broodstock. Anguilla japonica. Aquaculture. 2020;522: https://doi.org/10.1016/j.aquac ulture.2020.735100

151. Izquierdo $\mathrm{M}$, Fernández-Palacios $\mathrm{H}$. Nutritional requirements of marine fish larvae and broodstock. CIHEAM - Options Mediterr. 1997;22:243-264.

152. Fernández-Palacios $H$, Izquierdo $M S$, Gonzalez M, Robaina L, Valencia A. Combined effect of dietary a-tocopherol and n-3 HUFA on egg quality of gilthead seabream broodstock (Sparus aurata). Aquaculture. 1998;161:475-476.

153. Izquierdo $M$, Fernández-Palacios $\mathrm{H}$, Tacon $\mathrm{A}$. Effect of broodstock nutrition on reproductive performance of fish. Aquaculture. 2001;197:25-42.

154. Nascimento T, De Stéfani M, Malheiros E, Koberstein T. High levels of dietary vitamin $E$ improve the reproductive performance of female Oreochromis niloticus. Acta Sci Biol Sci. 2014;36:19-26.

155. Erdogan M, Arslan T. Effects of vitamin E on growth and reproductive performance of pindani (Pseudotropheus socolofi Johnson, 1974). Aquaculture. 2019;509:59-66. https://doi.org/10.1016/j. aquaculture.2019.05.019

156. Canyurt MA, Akhan S. Effect of dietary vitamin $E$ on the sperm quality of rainbow trout (Onchorynchus mykiss). Aquacult Res. 2008;39(9):1014-1018. https://doi. org/10.1111/j.1365-2109.2008.01952.x

157. Xu H, Huang L, Liang $M$, Zheng $K$, Wang $X$. Effect of dietary vitamin $\mathrm{E}$ on the sperm quality of turbot (Scophthalmus maximus). J Ocean Univ China. 2015;14(4):695-702. https://doi.org/10.1007/ s11802-015-2555-7

158. Nagarajan R, James R, Indira S. Effect of dietary vitamin E on growth, gonad weight and embryo development in female red swordtail, Xiphophorus helleri (Poeciliidae). Isr J Aquacult-Bamid. 2011;63:640-646

159. Miller GW, Labut EM, Lebold KM, Floeter A, Tanguay RL, Traber MG. Zebrafish (Danio rerio) fed vitamin E-deficient diets produce embryos with increased morphologic abnormalities and mortality. J Nutr Biochem. 2012;23(5):478-486. https://doi.org/10.1016/j. jnutbio.2011.02.002

160. McDougall M, Choi J, Truong L, Tanguay R, Traber MG. Vitamin E deficiency during embryogenesis in zebrafish causes lasting metabolic and cognitive impairments despite refeeding adequate diets. Free Radic Biol Med. 2017;110:250-260. https://doi.org/10.1016/j. freeradbiomed.2017.06.012

161. James R, Vasudhevan I, Sampath K. Effect of dietary vitamin E on growth, fecundity, and leukocyte count in goldfish (Carassius auratus). Israeli J Aquacult - Bam. 2008;60:121-127.

162. Hemre G, Mangor-Jensen A, Lie O. Broodstock nutrition in turbot (Scophthalmus maximus) effect of dietary vitamin E. Fiskeridir Skr Ser Ernaer. 1994;8:21-29.

163. Lie O, Mangor-Jensen A, Hemre G. Broodstock nutrition in cod Gadus morhua effect of dietary fatty acids. Fiskeridir Skr Ser Ernaer. 1993;6:11-19.

164. Tokuda M, Yamaguchi T, Wakui K, Sato T, Ito M, Takeuchi M. Tocopherol affinity for serum lipoproteins of Japanese flounder Paralichthys olivaceus during the reproduction period. Fish Sci. 2000;66:619-624.

165. Huang B, Wang N, Wang L, et al. Vitamin E stimulates the expression of gonadotropin hormones in primary pituitary cells of turbot (Scophthalmus maximus). Aquaculture. 2019;509:47-51. https://doi. org/10.1016/j.aquaculture.2019.05.023

166. Maulu S, Hasimuna OJ, Haambiya LH, et al. Climate change effects on aquaculture production: sustainability implications, mitigation, and adaptations. Front Sustain Food Syst. 2021;5. https://doi. org/10.3389/fsufs.2021.609097

167. De Silva SS, Soto D. Climate change and aquaculture: potential impacts, adaptation and mitigation. In: Cochrane K, De Young C, Soto D, Bahri T eds. Climate Change Implications for Fisheries and Aquaculture: Overview of Current Scientific Knowledge. FAO Fish. Aquacult Tech Pap. No. 530, FAO, 2009:151-212.

168. Freeman EO. Impact of climate change on aquaculture and fisheries in Nigeria: a review. Int J Multidiscipl Res Dev. 2017;4:53-59.

169. Adhikari S, Keshav CA, Barlaya G, et al. Adaptation and mitigation strategies of climate change impact in freshwater aquaculture in some states of India. J Fish Sci Com. 2018;12:16-21.

170. Hardy RW. Utilization of plant proteins in fish diets: effects of global demand and supplies of fishmeal. Aquacult Res. 2010;41:770-776.

171. Kim S, Less J, Wang L, et al. Meeting global feed protein demand: challenge, opportunity, and strategy. Ann Rev Anim Biosci. 2019;7:221-243.

172. Gieseg S, Cuddihy S, Hill J, Davison W. A comparison of plasma vitamin $C$ and $E$ levels in two Antarctic and two temperate water fish species. Comp Biochem Physiol Part B: Biochem Mol Biol. 2000;125:371-378

173. Horváth M, Babinszky L. Impact of selected antioxidant vitamins (Vitamin A, E and C) and micro minerals ( $\mathrm{nn}, \mathrm{Se}$ ) on the antioxidant status and performance under high environmental temperature in poultry. A review. Acta Agric. Scand. A- Anim Sci. 2018;68:152-160.

174. Yun SH, Moon YS, Sohn SH, Jang IS. Effects of cyclic heat stress or vitamin $\mathrm{C}$ supplementation during cyclic heat stress on HSP70, inflammatory cytokines, and the antioxidant defense system in Sprague Dawley rats. Exp Anim. 2012;61:543-553.

How to cite this article: El-Sayed A-FM, Izquierdo M. The importance of vitamin $E$ for farmed fish-A review. Rev Aquac. 2021;00:1-16. https://doi.org/10.1111/raq.12619 